\title{
The Current Practices of Active Learning in Amhara Region Police College, Amhara Regional State, Ethiopia
}

\author{
Kefialew Yenyet \\ Department of Education, Debre Markos University, Ethiopia
}

\begin{abstract}
The main purpose of this study was to assess the current practices of active learning in Amhara Region Police College in teaching police science. To congregate the objective of the study, mixed research design was employed. Simple random sampling for cadets and census method for instructors' was used to select cadets and instructors of Amhara Region Police College. Quantitative data were collected from cadets and instructors using structured and pretested questionnaire. The academic director and research department head were interviewed using interview guide. Data analysis was done in three phases. First, analysis of the quantitative data was done in SPSS Version 24 and percentages, means and a frequency, second, qualitative data was analyzed considering the research question, by using descriptive which is a deductive approach. Finally, quantitative and qualitative results were merged. The findings indicated that almost all instructors and cadets had awareness about active learning. Sometimes instructors are practicing active learning but the level of their practice was not satisfactory. Lecture was found to be the most commonly used teaching technique followed by individual assignments, group work/discussion and question and answer methods. Large class size, lack of administrative support, lack of materials or equipment needed to support active learning and cadets lack of interest on active learning methods were rated as the factors that have been negatively affecting the practice of active learning in Amhara Region Police College. Thus, it is critically important that instructors should be committed to discharge their roles to exercise active learning, the administration of the college and other stakeholders should design and implement a mechanism to monitor the practice of active learning, the concerned bodies of the college should design different mechanisms to avoid these problems by appropriately allocating the time, revising crowded materials and avoiding large and unnecessary contents to practice active learning in Amhara Region Police College.
\end{abstract}

Key words: Active learning, practices, Amhara Police College, cadets, instructors

DOI: $10.7176 /$ RHSS/10-15-05

Publication date:August $31^{\text {st }} 2020$

\section{Declaration}

I, the undersigned, declare that this thesis is my original work and has not been presented for a degree in other university, and that all sources of material used for the thesis have been fully acknowledged

Name: Kefialew Yenyet Mitiku

Signature

Date

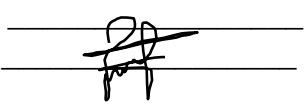

Unit one

\section{Introduction}

This chapter presents the background of the study, statement of the problem, basic research questions of the study, objectives of the study, significance of the study, delimitations of the study, limitations of the study and operational definitions of terms.

\subsection{Background of the study}

Education is a universal practice through which students acquire knowledge, develop skill and change in behavior. Realization of goals of any education requires effective teaching and learning process which in turn needs different teaching methodologies to meet the demand of the new generation (ICDR, 1999).

In the era of globalization and technological revolution, education considered as the first step for every human activity. It plays a vital role to develop human capital and linked with an individual's well-being and opportunities for better living (Battle \& Lewis, 2002) cited by (Temesgen, 2016).

Education is a means by which people develop and acquire knowledge, skills, values and attitudes. It paves the way for development and plays vital role which serve as a catalyst in bringing socio-cultural, economical, technological, political and environmental advancements. However, to meet these goals or to meet quality education, the teaching learning process at all educational institutions should be supported by strong two-way communications, (teacher - student or student - student) (Tesfaye, 2015).

Active learning of ideas and skills can occur in a variety of thought-stimulating activities, ranging from direct learning of ideas that explained in a web-page, book, lecture, video, TV or radio show to learning by 
discovery as in doing an experiment and then trying to discover one's own explanations for what, or in design projects and other kinds of problem solving. These activities can produce active learning, because educationally productive mental activity can occur with or without physical activity in which a variety of mentally active experiences (Craig Rusbult, 2007).

Active learning is used to describe a classroom approach which acknowledges that learners are active in the learning process by building knowledge and understanding in response to learning opportunities provided by their teacher. This contrasts with a model of instruction whereby knowledge imparted or transmitted from the teacher to students. Active learning means that learners take increasing responsibility for their learning, and that teachers are enablers and activator of learning, rather than deliverers of ideas (Rudolph \& Orwin, 2005).

Active learning is about learning through doing, performing and taking action. The action can either mental or physical and it usually contrasts with a conventional lecture method (Biruh, 2018). It involves students' active participation in course material through carefully constructed activities. Active involvement of students in teaching learning processes in the classroom and outside the classroom, which enables them to develop critical thinking skills (Birhanu, 2018).

Studies show that the best designed active learning approach is more effective than traditional method of teacher centered approach of teaching. For instance, Peter et al. , (2002:4) cited by (Biniyam, 2014), indicated that student from learner centered curricula are superior to their counter parts from traditional curricula with respect to their approach, perceptions of their education, long-term retention of knowledge and motivation for learning. The learner centered method based on the fact that, students who are given the freedom to explore areas based on personal interests, and who accompanied in their striving for solutions by a supportive understanding facilitator, not only make high academic results but also experience and increase in personal values, such as flexibility, self-confidence, social skills and problem solving capacity.

In the Ethiopian context, the new Educational Training Policy of Ethiopia emphasizes to develop problem solving capacity and culture in the context of education, curriculum structure and approach, focusing on the acquisition of scientific knowledge and practicum (MOE, 1994). In addition, the general goal of education has education geared towards the development of physical, mental, potential and problem solving capacity of people by expanding education and in particular by providing a basic education for all. Furthermore, the policy indicates that the general goal of the education and training policy is to cultivate the cognitive, creative, productive and appreciative potential of citizens by appropriately relating education to environment and social needs (MOE, 1994). Therefore, the new education policy calls for active learning method as the basis of the teaching and learning process.

Amhara Region Police College gives different training for police trainees based on the state and regional situational analysis. But the current state of formal police training programs was generally low in quality according to 2009 E.C. impact assessment research report of ARPC.

Now the college is hosting many police officers in different fields of police professions. To expand these professions in police institution, better teaching and learning principles is needed to increase the effectiveness of graduates.

Therefore, the purpose of this study was conducted to assess the current practices of active learning in ARPC.

\subsection{Statement of the Problem}

In Ethiopia, the current curriculum calls for emphasis on an active learning, and demands teachers to use active learning. However, little attempt is made by the policy document and other education strategy documents to give elaborations and to show how active learning can be translated into the teaching learning process at the classroom level (Belihu, 2010).

Learner-centered pedagogy is most commonly understood by education staffs at different levels. This is only speaking about the term active learning without mastering it and thereby providing a support system for teachers. Under such circumstances, curriculum designers, textbook writers, teacher training institutions, education experts, and teachers all followed their own way in implementing this approach (Belihu, 2010).

The dynamics of policing, strategies have changed time to time. Police executives are requiring their police officers to become problem solvers. These officers must now work with and through the public and community resources in a collective, collaborative approach. This new paradigm has existed for decades and yet the way that police officers are trained has not significantly kept speed with these new requirements (Kooi, 2006).

New innovations and theories in how people learn suggest that adults learn differently than children. Adults are more engaged learners who bring more personal experiences to the classroom. The adult learner expects to be an active participant in the classroom. He/she is expected to explore new topics, reflect on past experiences to interpret the new material, and relevancy in the subject matter to their lives. Problem-based learning methodology is one possible alternative to the way students and police recruits are taught (Kooi, 2006).

Police academy training and education develop the minds, career goals, and attitudes of future police 
officers who will be in charge of law enforcement and social order (Déverge, 2016). The police education concerned with the standard of police service, social foundation of a public safety. For a police officer it is important, in addition to knowledge of the law enforcement, to have an understanding of the nature of society, communities and individuals to solve problems easily.

In 2010 E.C. Amhara Region police commission report showed that now a days the community policing implementation of crime prevention in our region shows that decline from time to time. As a result, the society becomes unconfident by police officers. This is not creating active participation of the society in crime prevention function.

In 2009 E.C. feedback was gathered from selected Amhara region zones and woreda society and police leaders; the data showed that few of trainees show good effort on crime prevention. But most of the trainees have weakness on effectively implement crime prevention. In order to train educated police officers and professional who are competent, versatile and relevant to the need of the society, it is very important to improve quality of

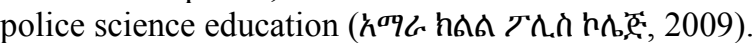

To effectively implement policing, police departments must make it a priority to educate police officers in the theories and practices of policing and problem-oriented policing, as well as train and encourage officers to translate program elements into actual field activities (Haarr, 2001).

Police officers respond to burglar alarms, enforce traffic laws, arrest different suspects, conduct different crime investigations, perform crime prevention, put out victims through vehicle accident and vehicle fires, put out victims from house fires, answer general questions about how to get somewhere from here, pull and complete many more diverse duties on a daily basis throughout a career. These responsibilities need practical teaching and learning or teaching by doing in the police academy and out of the academy.

The Education and Training curriculum of ARPC highly encourages a paradigm shift from teacher-centered to student-centered approach. Student-centered approach leads to effective teaching learning and promotes the development of student's critical thinking and to engage them in the teaching learning process actively and effectively. With this context, Amhara region police commission needs educated and capable police officers and leaders. To play their roles in ensuring national and regional endeavors of rapid economic development, peace, and decentralization process educated police officer is important. This becomes true when higher police education prepares students who are well equipped with knowledge, skill and attitude. Mere knowing of facts or principles in their learning may not enable them to perform their intended activities. Therefore, students should be encouraged to focus on understanding in their learning and they have to have the ability to apply it in different context at their work place (Amhara Region Police College, 2015).

The levels of implementation of active learning practices are different in different institutions. Teachers at all levels of education are expected to implement active learning to attain the desired goal. But researches and experiences have shown that there is a difference between theory and practice in Ethiopian context (Tesfaye, 2015). This is to mean that what has been stated in the policy might not be implemented practically due to some reasons. In relation to this topic, many studies have been conducted in different parts of the country at different levels of the schooling. For example, Different researchers conducted different researches' about the implementation of active learning in primary school and universities.

The researcher has tried to see other related researches done by others. However, most of the researches have been done are based on the implementation of active learning in primary school and universities. For example, Daniel (2014) conducted a research on the implementation of active learning and continuous assessment in Pentecostal theological college and this implies that this work more or less concentrated on continuous assessment. Furthermore, Teshome (2017) also conducted a research on classroom participation and development of student attitudes a study of active learning practices in Ethiopian primary education; he concentrated on classroom participation and development of student attitude on active learning. Moreover, some others also conducted researches on similar issues like Mulatu \& Bezabih (2018) on the effects of teachers' perceptions on the implementations active learning in EFL classroom the case of secondary school.

Generally they found the implementation of active learning was low because of the lack of budget, large class size, due to the perception of teachers about active learning, lack of training are the factors that hinder the implementation of active learning (Daniel, 2014), (Teshome, 2017), (Mebratu, Mulatu \& Woldemariam, 2018), ), (Biruh, 2018).

However the above researchers conducted their research based on selected elementary school, secondary school and civil universities. What sets this study apart from other studies is the fact that the police college learning process is different from the above educational institution. So, the law enforcement professions need unique teaching and learning environment with different learning approach from the above educational institution. Therefore, all these researches do have relations one another since they share something in common i.e. they all are studies on the implementation of active learning.

With this regard, the researcher believed that he had to search other more related research done by others because all the researches mentioned above are the implementation of active learning. Even if they are the 
practices and implementation of active learning and they share the same thing with this research. But the current research relies especially on practices of active learning in ARPC. Therefore, Biruh (2018) conducted a research on an assessment of practice of active learning approach in Wolita Sodo University Health Science College. However, his research has covered only the universities specially Health Science Colleges. It did not include police academy. As it is known police officers and health professionals do have quite different works in the task areas. Taking this fact in to account, this study was aimed at assessing the current practice of active learning in police academy.

Moreover to the knowledge of the researcher, there is no research work done in relation to active learning in Amhara Region Police College. Therefore in order to fill the above gap, the aim of this research was to assess the current practice of active learning and to examine what factors that hinder its implementation in Amhara Region Police College.

\subsection{Research question of the study}

This study will answer the following basic questions.

1. How do Amhara Region Police College instructors and cadets knowledge of active-learning?

2. To what extent active learning is implementing in Amhara Police College?

3. What are the challenges that affect the implementation of active learning?

\subsection{Objectives of the study}

\subsubsection{General objective}

The general objective of this study was to assess the current practices of active learning in Amhara Region Police College.

\subsubsection{Specific objectives}

$>$ To identify the current practices of active learning in Amhara Region police college.

$>$ To examine the perception of Amhara Region Police college instructors and cadets towards active learning.

$>$ To identify the challenges that hinders the implementation of active learning in Amhara Region Police College.

\subsection{Significance of the study}

This study will assess the practices and challenges of active learning approach in Amhara region Police College. So, the result of this study will show the level and practice of active learning approach in Amhara Region Police College, It will contribute to improve the teaching learning approach in Amhara Region Police College by identifying the major challenges to implement active learning in Amhara region Police College. It will help the instructors of Amhara Region Police College to evaluate their usual teaching approach and it may initiate other educational researchers to conduct similar study in Amhara Region Police College.

\subsection{Delimitation of the study}

In order to carry out any research, it is important to delimit the scope of the study to manage the size. Therefore, the scope of this study delimited to teachers' and cadets which deserve the practice of the active learning in the case of Amhara Region Police College. The logistic and time constraints have forced the researcher to delimit this study in Amhara Region Police College instead of considering other regional and federal police colleges. Therefore, it attempts to access the current practice of active learning in the Amhara Region Police College.

\subsection{Limitation of the study}

This study has got some constraints. Primarily, it is worth keeping in mind that the sample size of the study was limited to only 128 respondents of instructors and cadets. This study did not see the confounding effects of variables how one variable affects another one in the interrelated manner. It did not incorporated other regional police colleges.

\subsection{Operational definition of terms}

Active learning: Student-centered or learner-centered learning, where students play an active role in their learning, with the teacher as an activator of learning, rather than an instructor (Rudolph \& Orwin, 2005).

Police College: Amhara region Police College that established by Council of Regional Government Regulation No. 53/2007, under the regulation as an autonomous having its own legal personality higher education and training college that is found in Debremarkos town located in the East Gojjam Zonal Administration (The Council of The Amhara National Regional State, 2007).

Cadet: A student at Amhara Region Police College who is training to be an officer the same meaning to students. Instructor: A teacher who teach police science in Amhara Region Police College which means a teacher. 
Understanding: it means the assumption or perception of instructors and cadets about active learning

Practice: how active learning is usually done in Amhara Region Police College.

Implementation: is how teaching-learning activity put into practice by teachers/instructors in educational institutions

Challenges: These refer to threats, problems and obstacles that may encounter on the implementation of active learning

\section{Unit Two}

\section{Related Literature Review}

This chapter highlights the different concepts of education and police education, theories of learning, types of instructional approach, concepts and principle of active learning, characteristics of active learning and benefits of active learning, techniques of active learning. In this chapter discussed teachers and students attitude towards active learning and factors that affect the practices of active learning.

\subsection{Education}

The term education has been interpreted by different people in different ways. Some people refer to it as formal schooling or to lifelong learning. Some others refer to it as acquisition of knowledge, skills and attitudes. Some say that education is nothing, but training of people's mind in a particular direction to bring about desired changes (Gupta et al., 2014).

This shows that education doesn't have one precise universally accepted definition. It has various meanings with various functions. Analysis of these meanings would help us to understand what education really is. To begin with, let us look into how the term education has evolved and some of the views of great thinkers that exemplifies the concept and meaning of education (Gupta et al., 2014).

According to etymological definition, education seeks to nourish the good qualities and draw out the best in every individual. Education seeks to develop the innate or the inner potentialities of humans. Some other educationists believe that the word education has been derived from the Latin term 'Educatum', which means the act of teaching or training. The meanings of these root words lead us to believe that education aims to provide a nourishing environment that would facilitate or bring out and develop the potentialities in an individual (Gupta et al., 2014).

Education is defined as the aggregate of all the processes by which a person develops abilities, attitudes and other forms of behavior of practical values in the society in which she/he lives; the social process by which people are subjected to the influence of selected and controlled environment especially that of the school, so that they may obtain social competence and optimum individual development.

Education is a systematic process through which a child or an adult acquires knowledge, experience, skill and sound attitude. It makes an individual civilized, refined, cultured and educated. For a civilized and socialized society, education is the only means. Its goal is to make an individual perfect. Every society gives importance to education because it is a panacea for all evils. It is the key to solve the various problems of life (John, 2012).

The different meanings and definitions of education as given above lead us to the conclusion that education should have a comprehensive definition. In Short, education is the development of individual according to his needs and demands of society, of which he is an integral part. The above remarks of different educators highlight the following special features of education: Education is both unilateral as well as bi-polar in nature, It is a continuous process, It is knowledge or experience, It is development of particular aspects of human personality or a harmonious integrated growth, It is conducive for the good of the individual or the welfare of the society, It is a liberal discipline or a vocational course, It is stabilizer of social order, conservator of culture, an instrument of change and social reconstruction(Kumar \& Sajjad Ahmad, 2008).

\subsection{Police education}

Basic police education is defined as an initial training for new recruits, who are former civilians, to teach them basic police competencies. Continuing education is defined as education for existing police officers. Mostly, after basic education, police force and police education institutions provide different types of trainings in-service to maintain acting police officers with operational skills, update knowledge due to legislation changes. This training can be mandatory or situational based on circumstances. the current attention being focused on increased educational requirements for law enforcement employment, police science programs have witnessed a phenomenal enrollment growth, particularly in terms of in-service students (Augustine et al., 1976).

Moreover, police forces and police education institutions offer programs aimed at a professional specialization, or less frequently these programs are geared to updating and certification of competencies specialized training. Management advanced education is frequently linked to promotion and is often provided before or after assignment to a new position in order to enhance management, leadership, supervisory knowledge, and skills (Dekanoidze \& Khelashvili, 2018). 
Military Education In modern time's military training is usually given only by the state authorities when recruits join the army. Education in the law enforcement field has been long debated. In the 1960s, the Law Enforcement Education program was created as a means to improve the quality of the police force in response to public criticism (Fritsvold, 2020).

In order to meet the needs of society, suitably designed education programs are necessary. The literature on policing guides us towards a focus on community policing which, through the use of andragogical strategies, fosters learning that remains with police recruits beyond the classroom and addresses cultural issues (Vodde \& Robert, 2009).

To raise standards in police training and to equip all police staff with the skills they need to do their jobs and deliver better policing. Training is only one part of a devising a comprehensive human resource strategy. The key challenge is to translate the best possible training into the best possible police contribution to reducing crime, delivering justice, protecting the public and building a safe society (Tavares-dos-Santos, n.d.)

Initial police academy training and education develops the minds, career goals, and attitudes of future law enforcement officers who will be in charge of social order. The needs and demands of modern-day societies have evolved, and it is very important for police training academies to keep up with the practice of the police profession (Déverge, 2016).

Basic police academy training varies across locations, but the British model of policing established by Sir Robert Peel in England during the 19th century served as the predominant model for policing in many countries such as the United States and Canada. Such policing models were established following the necessities of society at that time and as such they were modeled under a military-authoritarian organizational design which is still in place in public police institutions both in Canada and the United States (Déverge, 2016).

To improve policing practice, it has been suggested that problem solving skills could be applied more effectively, especially in relation to community policing, where police address the underlying causes of crime with community stakeholders. Police problem based learning appears to provide the benefits of a learner centered/active learning/ approach clearly needed as an additional strategy in police education (Shipton, 2009). Science must become a natural part of police education, and police education must become based in science (Weisburd \& Neyroud, 2011).

Police education should make greater use of adult learning principles that encourage a learner centered approach, promoting critical thinking skills within authentic learning contexts related to their policing duties (Shipton, 2009).

The majority of the police force is considered adult learners, it is important to explore the characteristics of adult learning theories and how it relates to police learning. In adult learning theories, the learner is involved and takes responsibility for his/her learning process. The learner self reflect, gathers information, collaborates with others and self-directed. Factors that influence learning are past life and work experiences, previous knowledge and past learning experiences (Orey, 2014).

The demands on policing in the 21 st century require that police training (knowledge and skills to fulfill police operations) and police education (conceptual skills for theoretical and analytical learning) are capable of meeting a range of expectations (Ryan, 2008).

\subsection{Theories of Learning}

Learning is a process of discovery that generates new understanding about ourselves and the world around us (Ramsden, 1993). Other psychologists and educators define learning in the way that they perceived the world around them. These different definitions for learning and the process of learning led scholars to develop learning theories. According Mcleod (2001) a learning theory is a systematic integrated outlook in regard to the nature of their process whereby people relate to their environments in such away to enhance their ability to use both themselves and their environment in a most effective way.

With these respect different learning theories have been developed starting from early period. Even though many theories are evolving from time to time, in one way or another they are categorized under one of the following major learning theories (Behavioral, cognitive, constructivist, humanistic and social learning theory). These major theories are the amalgamation of other many theories, which have relatively similar stance about learning and the occurrence of learning.

Behavioral learning theory, learning is a change in observable behavior, which occurs through stimuli and responses becoming related according to mechanistic principles (Ormrod, 2012). Behavioral learning theory interprets learning in terms of changes in strength of stimulus- response connection, associations, habits, or behavioral tendencies. With this theory, learning is perceived teachers ${ }^{\text {ee }}$ desire is to change the observable behaviors of students in a significant way.

Cognitive learning theory, learning is perceived as a process of gaining or changing insights, outlooks, expectations or thought patterns. They define learning in terms of re-organization of perceptual or cognitive fields so as to gain understandings. Here the assumption is that, humans are logical beings who make the choices 
that make the most sense to them. Pure cognitive theory largely rejects behaviorism on the basis that behaviorism reduces complex human behavior to simple cause and effect. In this theory the teacher aspires to help students develop their understanding of significant problems and situations (LaTefy, 2016).

Constructivist learning theory explains human learning as an active attempt of construct meaning in the world around us. Constructivists believe that learning is more active and self directed than either behaviorism or cognitive theory would postulate. The constructivist position maintains that learning is a process of construction meaning; it is how people make sense of their experience (Caffarella \& Merriam, 1999). Followers of this theory believe learner centric instructional classroom method will strengthen the commitment and involvement of self motivated learners because of their high level of interaction. Having these philosophical outlooks or learning theory, students learning can be influenced by their environments in our case, especially of classroom environment.

We cannot conclude that all teachers will rely on one theory in their lessons rather they can be flexible in a different situation. What is important here is that, teachers should create an environment which results a maximum learning on the side of students. Based on the available context of the learning environment, students will adopt an approach which enables them to interact and survive the existing situation.

Active learning assumptions are derived from a variety of sources in cognitive psychology, learning theory and educational philosophy. The loosely linked set of beliefs is closely associated with social cognitive constructivism, but also carries strong remnants of pragmatic approaches advocated by American philosopher John Dewey and later, proponents of authentic learning and reflective practice (LaTefy, 2016).

\subsection{Types of instructional approach}

Methods of teaching can be classified as traditional and modern methods depending on their nature of involvements of students and teachers, the aim of education process, their recentness. In line with this, (Capel et. al., 1995) supplemented that the classification of methods as direct (teacher centered, traditional, formal, expository, didactic, authoritarian etc) or indirect (student centered, democratic, active, informal, repressive etc) would be made on the basis of source of the knowledge, role of the teacher, role of the students and mechanism of evaluation Finally, despite the variation in the names, it is witnessed that these terms have common features for their classifications. It is therefore, worth mentioning that these terms are implied by the terms teacher centered Vs learner centered (active learning) methods in this study.

\subsubsection{Teacher Centered Approach}

This approach gives the priority role and responsibility to the teacher. The teacher is considered as the center of classroom activity, and is thought to hold most of the knowledge necessary for the students to be successful (ICDR, 1999). The information to be learned is given to the learners in a completed form instead of letting the learners to interact with. Similarly, Eggen \& Kauchax, (1996) described that teacher-centered instruction refers to academically focused, teacher directed classroom using sequenced and structured materials. It refers to teaching activities where goals are clear to students, time allocated for instruction is sufficient and continuous, coverage of content is extensive, the performance of students is monitored, and feedback to the student is immediate and academically oriented. Moreover, the teacher plays a primary role in structuring content, explaining it, and using examples to increase students understanding. In line with this idea, Borich, (1984) argued that in this approach the teacher acts as the director of learning and the assumption is made that the teacher knows best. Teaching takes a predominant role over learning. Indeed, students are assumed to be "Empty Vessels" that have to be filled by the teacher. In this case, the teacher will do most of the talking and it is the student's duty to listen to what the teacher has to say, memorize and repeat it during reaction period or in examination papers (Eggen \& Kauchax, 1996).

According to ICDR (1999) in this mode of teaching, the teacher uses "chalk and talk" or other methods of teaching in which he/she is active and students stay passive. The teacher either writes notes on the board, which the students passively copy in their exercise books, or memorize the information from their textbooks. (Frazee \& $\mathrm{Al}, 1995)$ explained that skills are taught by the teachers telling, describing, demonstrating and explaining the desired technique step by step in their attempt to master the techniques via drills, practice and recitation. Macharia \& Waria, (1994) have summarized some essential characteristics of the teacher centered approach as follows:

The teacher is more active than the students; the teacher is active in explaining, monitoring and describing. The learners listen passively while the teacher pours knowledge in to them the desks are arranged in straight rows. The main activity of the learners is listening and perhaps copying notes from the chalkboard and there is usually no group work

Therefore, teacher oriented methodology is the rigid, stereotyped patterns of behavior instead of flexible patterns that can be applied to a variety of life situations. To sum up, such arguments seem to be sufficiently convincing that in the teacher centered classrooms, learners are the passive receivers of knowledge. Teachers and texts are sources of authority. Lecture format dominates, and students learn in a rote fashion, reproducing the 
subject matter in set exercise, and in examinations. Moreover, the emphasis is on theory rather than on practice and the successful student is the one who can display his knowledge of facts that has been fed in to him/her.

\subsubsection{Active Learning/student center/ approach}

Active learning has received considerable attention over the past several years. Often presented or perceived as a radical change from traditional instruction, the topic frequently polarizes faculty (Michael, 2004).

It is not possible to provide universally accepted definitions for all of the vocabulary of active learning since different authors in the field have interpreted some terms differently. However, it is possible to provide some generally accepted definitions and to highlight distinctions in how common terms are used.

Active learning is defined as any instructional method that engages students in the learning process. In short, active learning requires students to do meaningful learning activities and think about what they are doing (Bonwell \& Eison, 1991).

Active learning refers to any activities where pupils are given a marked degree of autonomy and control over the organization, conduct and direction of the learning activity. Most usually, such activities involve problem-solving and investigational work, and may be individualized such as an extended piece of work or project or involve small group collaboration such as small group discussion, games, a role-play simulation or collaborative project (Kyriacou, 2007).

According to Silberman, (1996) definition, active learning is an approach to instruction in which students engage the material they study through reading, writing, talking, listening, and reflecting. Active learning stands in contrast to "standard" modes of instruction in which teachers do most of the talking and students are passive.

Active training is also defined as making participants work within a cooperative learning context. Instructional use of small groups is needed so that students work together to maximize learning (Chervase, 2016). (Michael, 2004) define "Active Learning is generally defined as any instructional method that engages learners in the learning process"

Active learning is a process whereby students engage in activities, such as reading, writing, discussion, or problem solving that promote analysis, synthesis, and evaluation of class content. Cooperative learning, problem-based learning, and the use of case methods and simulations are some approaches that promote active learning (Peggy, 2016).

Active learning is basically one form of learning approaches, action-oriented students. Activity -oriented learning implies that students learning system placing students as active subjects and students who already have a readiness to learn (Nurma, 2017).

Researchers and authors have interpreted it in various ways. Michael Prince explains, Active learning is generally defined as any instructional method that engages students in the learning process. In short, active learning requires students to do meaningful learning activities and think about what they are doing. Prince's definition is drawn from foundational work done by (Bonwell, and Eison, 1991) has been widely accepted.

Amhara Region Police College employs a problem-based learning and service delivery learning approach combined with lectures on factual content. These methods help students develop self directed and interdependent learning. One of the goals is to promote student responsibility and engagement through a collaborative approach. A consistent, respectful, and supportive classroom atmosphere helps students to feel safe in asking questions and contributing actively to discussions. The approach also helps students to increase their capacity and skills in preparing operational plan, conducting inquiries and overcome the challenges in law enforcement practices (Amhara Region Police College, 2015).

\subsection{Principle of active learning}

Learning involves the active construction of meaning by the learner. This well-established principle involves the fact that students link new information with information that they already know. New and old information are assembled into mental models. If the old information is faulty, that compromises the learning of new information. Learning can be thought about as a process of conceptual change in which faulty or incomplete models are repaired (Weimer, 2012).

Learning facts and learning to do something are two different processes. This explains why students can know a set of facts and still be unable to apply those facts to solve a problem. If students are to successfully use knowledge, they must have opportunities to practice and obtain feedback. A variety of other instructional advice follows from this principle including the fact that, students who are learning to solve problems need to know more than whether the answer is right or wrong. The sequence of problems from easy to hard is also important. Students should only move to harder problems as they improve. Moving students too fast or before they are ready compromises their efforts to learn (Weimer, 2012).

Some things that are learned are specific to the domain or context (subject matter or course) in which they are learned, whereas other things are more readily transferred to other domains. What's at issue here is knowledge transfer and whether students can take what they know about one subject or topic and transfer that knowledge to another subject or topic. As many college teachers have observed, students often have great 
trouble with this. There are still a number of research controversies in this area, but there is growing recognition that transfer involves skills that students need to be taught(Weimer, 2012).

Individuals are likely to learn more when they learn with others than when they learn alone. Many faculties are very independent learners and so struggle a bit with accepting this principle. However, it is based on impressive results in different disciplines that support the power of getting students to work together to learn(Weimer, 2012).

Meaningful learning is facilitated by articulating explanations, whether to one's self, peers, or teachers. Students learn to speak the languages of disciplines when they practice speaking those languages. That's part of what this principle involves, but it is also true that articulating an answer, an idea, or a level of understanding aids in learning. The speaking or writing makes clear to the learner what they do and don't understand, and/or their understanding deepens as they frame a description that is meaningful to them (Weimer, 2012).

\subsection{Characteristics of active learning}

Using an active learning environment can enhance the integration of practice and theory in the classroom. Active learning is using instructional activities involving students doing things and thinking about what they are doing. Some characteristics of active learning are students are involved in more than listening, less emphasis is placed on transmitting information and more on development of students' skills, students are involved in higher order thinking (analysis, synthesis, and evaluation), students are engaged in activities such as writing, reading, discussing, and observing and greater emphasis is placed on students' exploration of their attitudes and values (Bonwell \& Eison, 1991).

Teachers obviously cannot do the act of learning on behalf of students, and students should be engaged actively with the learning process if we want them to understand the lesson. For this reason active learning is meaningful learning. Some authors use the expression of 'deep learning' or 'meaningful learning' as opposed to 'shallow learning' where very little understanding takes place. Active learning provides students with meaningful learning by allowing them to take more responsibility in their own learning (Kirpik, 2012).

\subsection{Benefit of active learning}

Many Studies shows that active learning has many benefits for students and teachers. It helps students to increase information retention and application of knowledge by improving their critical thinking and problem solving skills. It also promotes motivation and teamwork which leads to enhanced understanding of course content. Additionally, active learning provides better confidence for students to use and improve their language proficiency. Bonwell \& Eison, (1991) explained that active learning is vital in the classroom because of its powerful impact up on students learning. Furthermore, several studies have shown that students prefer strategies that promote active learning to traditional teaching approaches.

Many researches show that there will be improvements in student- faculty interaction student- student interaction, academic achievement, communication skills, higher level thinking skills, team work, attitude towards the subject and motivation to learn (Silberman, 1996).

Active learning therefore, plays important role to move students from passive recipient to participants who have their own role in their learning processes. This is due to the fact that active learning is not only a set of activities, but an attitude on the part of the teacher and the learner that makes learning effective. More specifically the purpose of active learning is to stimulate life time habits of thinking to stimulate students to think about HOW as well as WHAT they are learning and increasingly to take responsibility for their own learning (Silberman, 1996). It also provides new learning resources and different learning styles which increases student's engagement and course satisfaction. According to Tricia, (2019) there are 9 benefit of active learning. These are:

\section{Develops collaborative skills}

Collaboration is a pillar of most active learning approaches. In increasingly team-oriented workplaces, students whose only experience is with essay writing and exams will find themselves at a disadvantage. By working together in breakout groups, students develop the abilities they'll need to collaborate in the workforce.

One important element of active learning is cooperative learning which focuses on group work. Cooperative learning is a learning process that could be simply considered as students working in small groups and helping each other in their learning. What lies in the beneath of grouping is the thought that students gain more through group work than they do individual/independent work (Kirpik, 2012).

\section{Encourages risk taking}

Students may initially resist the move to active learning - after all, it's easy to sit in class and take notes (or zone out) until the talking is done. Active learning pulls students out of their comfort zone by creating an environment where risk taking is encouraged. As they get more comfortable sharing their thoughts, defending their conclusions and building on each other's ideas, they'll gain confidence and self-possession.

Requires student preparation

There were likely courses that didn't require much day-to-day effort beyond simply showing up to class. You 
could be tired or disengaged, and the proof likely didn't notice especially if you hid in the back rows of the lecture hall. But in an active learning classroom, no one's invisible. It's immediately apparent when students haven't taken the time to prepare, so there's greater motivation to show up in mind and body.

\section{Increases engagement}

Students who are actively learning are actively engaged. Whether solving a problem, debating an issue or researching a concept, they are processing ideas and forging deeper understanding. If you're looking for new ideas to get your students thinking.

\section{Improves critical thinking}

In a world where fake news has become part of our daily discourse, the ability to identify a legitimate source or spot a faulty argument is only becoming more important. Active learning shifts the focus of learning - from passively (and possibly unquestioningly) digesting information to being accountable for actively engaging with sources and perspectives. And when students share ideas, they learn to build stronger arguments, challenge presumptions and recognize leaps of logic.

\section{Increases retention}

According to Dale's Cone of Experience, students remember about $10 \%$ of what they read, $20 \%$ of what they hear, but $90 \%$ of what they do. Active learning classrooms are, well, more active students are often applying their ideas, working on collaborative projects or using approaches makes tech more powerful (E. Dale, 1969).

In contrast to lecture halls, which can rely on display technology used only by the instructor, many active learning classrooms are filled with collaborative tools that are used by the students themselves.

\section{Sparks creative thinking}

Creativity is one of the key skills needed for the workplace of the future and one of the hardest to teach using traditional methods. Active learning helps students understand that creativity goes beyond the traditional moment, it develops with effort and hard work. With lots of practice flexing their creative muscles, students also see how both individual reflection and collaborative exchange can lead to better ideas and more novel solutions to problems.

\section{Promote real problem solving}

The ability to solve complex problems was called out by the World Economic Forum as the most important skill needed for future jobs. Students in active learning classrooms understand that no one has all the answers, so it's up to them to figure them out.

\subsection{Common techniques of active learning}

Fink, (2003) explains that the difference between teaching techniques and instructional strategy as a teaching technique is a separate, specific teaching activity and instructional strategy is a set of learning activities. There are many techniques which promote students to have active learning in classroom and outside classroom. Following are the most common and widely utilized teaching techniques which encourage students to have active involvement in classroom and understand the subject in a better way out of the class.

\section{Group Work/Discussion Groups}

One of the most common techniques used in classroom is group work. In group works everyone in the group has a chance to participate and everyone has a role to play to accomplish the given task together. If it is properly organized and managed, group work enables students to learn more and to remind their interdependence (Birhanu, 2010).

Group work is part of collaborative strategies of teaching learning. It is one of the best ways of encouraging active learning by arranging the learners' work together in group. It can take many forms involving pairs of students working together, up to ten learners together or it can involve students who work individually and come together in groups to compare and discuss the results of their group. If necessary, random, gender, interest and ability groups can be formed (Kyriacou, 2007)

\section{Questioning}

Questioning is another active learning technique which promote students to actively participate in the teaching and learning process. It is an easy technique in which questions are asked during lecture to hold student's attention and assess their understanding (Pual et al., 2005).

\section{Think-Pair-Share}

It is one of the effective active learning techniques which allow students to think the solutions to a given problem individually and subsequently share their outcomes with a partner and larger group. With this technique, students will be active by having dialogue with self and others about the given problem (Fink, 2003).

\section{Demonstration}

This active learning technique is when the instructor demonstrates how to do something in front of students and let the students do something in front of their friends and the teacher. It enhances retention by showing the students how to do something in both words and actions. It needs good planning and the necessary equipments should be ready (Morgan et al., 2014). 
Demonstrations can also serve as a vehicle for instructors to share attitudes about the tentative and changing nature of knowledge in their discipline, with a goal of motivating students to engage in experimentation on their own (Charles \& James, 1991).

\section{Role play}

Role playing is the other important teaching technique which is a powerful technique for motivating learners and developing or changing learners' attitude (Gezahegn, 2013) cited by (Biruh, 2018). Role playing is unrehearsed dramatization of a certain situation in which players try to act what they would do and how they would react in that situation.

\section{Brainstorming}

Brainstorming is a technique used with a group to generate a large number of ideas quickly. It actively engages students in the learning process. Brainstorming is a valuable activity because it is unlikely that if students worked alone that they would come up with the same volume of ideas. It can be used to introduce a new topic, revise a topic or solve a problem (Birhanu, 2010).

\section{Case Studies}

A case study is a real or imaginary scenario which describes an event or situation which students are required to read, understand and solve problems/questions based on the case study. Students can work on the case study individually or in small groups. Case studies can be used across all course areas and it gives students the opportunity to be realistic, creative and practical (Birhanu, 2010).

\section{Project Method}

A project is a natural learning activity involving the investigation and solving of problems by individuals or a group of trainees. It should consist of a task in which a trainee sets out to achieve some definite goal of real personal value (ICDR, 1999).

\section{Peer teaching}

Peer teaching is an instructional technique which results in deep learning. It is a participatory and active strategy in which students teach each other. It involves use of students in the class who have experiences and good background in particular area. Many studies proved that peer teaching is extremely effective for improving learning in the class room (Debela, 2017).

\subsection{Teachers' and Students' Attitude towards Active Learning}

For effective implementation of any new perspective, including active learning, positive attitude to the issues and sound knowledge and skills in the area are very important. Particularly, the underlying ideas, concepts, merits and demerits of the new approach should clearly be understood by teachers and students.

Teachers' Attitudes: It is critical that teachers/ instructors have a thorough understanding of the nature and characteristics of the appropriate teaching- learning methods to be used in conjunction with curricular materials. Because, although to a certain extent some decisions may be determined for teachers/ instructors by official syllabus, students ${ }^{\text {ee }}$ textbooks or teachers ${ }^{\text {ee }}$ guide, it is the teacher/ instructor who are the ultimate implementer of the curricular materials (ICDR, 1999). But, unfortunately some teachers discourage active learning with the ground that it brings an extra demand in the planning and preparation of lessons. Some teachers feel as it is bounded by overcrowded subject matter and thus pressurized by the limited time they have to teach.

The belief persists that active learning takes too much time and thus covering the portion is difficult or impossible. Even, they come to the conclusion that active learning may be nice in theory but unrealistic in practice. These all show that there have been no enough and concrete perception about how to install active learning in classroom, which may lead to negative reactions (Capel et. al., 1995). These misconceptions show that teachers have not understood as active learning enables them to spend more time with groups and individuals to give access to special needs of students and contribute to a better and quality learning.

Students' Attitude: Authors like Dary and Terry (1993) have stressed the importance of students past experience, which is a transformative rather than passive accumulation of knowledge. They notice that unless learners consider the implication of the ideas there in their own lives and decide to act, know and believe in the ways; they are likely to adopt a passive acquiescence to the teachers' knowledge structure. And ultimately, this passive students learning has not made a difference because it has not been transformative and at best resulted in some accretion of knowledge. Thus, it is possible to suggest that active learning seeks the emancipation of learners from the old belief that has dominated methods of teaching over the last century.

However, in spite of all the contributions of active learning discussed earlier, the students may not have appropriate perception and may have developed negative attitudes for various reasons. For example, students may look shy and uncooperative at the beginning of active learning. Because, they are accustomed to the traditional instructional method where they are expected to listen attentively and try to memorize what have been learned for the purpose of examination. This discloses that learners are not trying and/or have no access to use their prior experience. They do not challenge their old assumption or they do not create new meaning or perspectives that are more inclusive, integrative and open to alternative views, which can emancipate them from 
strong belief on stimulus response mechanisms (Dary and Terry, 1993).

\subsection{Factors Affecting Active Learning}

It is common that like any educational issue in the teaching-learning process, active learning too may face different factors during its implementation in the real classroom conditions.

\subsubsection{The Training of Teachers}

The success of educational process depends to a great extent on the character and ability of teachers. Teaching in the modern school must be vastly enabled to produce better-educated person in the world. Teachers must know much more about subject matter, methods of teaching the learner and his growth, the setting for and environment of learning, about the interaction between learner and environment.

Therefore, the modern professional teacher must possess a system of principles habits of thinking which guide the operational process. Scholars have suggested that, if education to be successful, next to curriculum, teacher training is of special significant, which needs consideration so as to maximize the development and changes in education (Gerhard, 1982) sited by (Desta, 2001).

Teacher's pedagogical skills can be improved by emphasizing courses that develop the teacher's ability to reason about the content of instruction. Teachers should have a sound knowledge of the curriculum and be able to transfer it to the learners. They must be able to analyze critically the material to the interest and abilities of their students. Teachers must be able to organize and manage the classroom, evaluate discipline, and encourage students in manner that promotes better learning (Desalegn, 2014).

\subsubsection{Teachers attitudes}

Teacher's attitude is the basic ground to act in a positive or negative way towards persons, ideas or events happening in the environment. And most educators are convinced the teacher attitudes are very important dimensions in the teaching process. Students with teachers of positive attitudes towards teaching and the curriculum are found to be high level achievers in learning. And consider the teacher's attitudes as very important aspects in the teaching process and suggested that teachers attitudes towards the subject taught is one of the common studied teacher characteristics. According to Gara \& Asrat, (2014) teacher's attitudes are very important and have the direct effect on our behavior; they determine how we view our selves and interact with the environment. Therefore, possession of a college degree not in any way ensure that teachers will be effective in their teaching unless and otherwise they have positive attitude to the subject and approaches of teaching.

\subsubsection{Administrative support}

Ornstein, A., \& Hunkins, (2009) suggest that "a trusting relationship must exist among all parties in the school especially between administration \& teachers. As implementation is a collaborative \& emotional effort, peer support is vital for effective implementation". In fact, it is not an individual activity many hands need to be put together for implementation to be successful such as directors staff administers.

\subsubsection{Students and teachers knowledge of the students-centered method of learning}

Some authors (Dary and Terry, 1993) cited by (Debela, 2017) have stressed the importance of the learners' past experience, which is a transformative rather than passive accumulation of knowledge. They notice that unless learners consider the implications of the ideas for them in their lives and decide to act, know and believe in new ways. They are likely to adopt a passive acquiescence to the teachers' knowledge structure. And ultimately, this passive learners' learning has not made difference because it has not been transformative and at the best resulted in some accretion of knowledge.

Thus, it is possible to suggest that student-centered learning approach seeks the emancipation of learners from the traditional method that has dominated method of teaching over the last century. Students may look shy and uncooperative at the beginning of the student-centered class room activities. Because, learners are accustomed to the traditional instructional method where they are expected to listen attentively and try to memorize what have learned for purpose of examination. This discloses that they do not try and have no access to use their prior experience.

\subsubsection{Class Size as a Factor}

Large class size may restrict the use of certain active learning strategies (e.g., it is difficult to involve all students in discussion in groups larger than 40) (Sasikumar, 2018). The aim of student centered method is with no doubt make all learners involved in the learning process without the influence of domination of top learners. For this to take place the communication among the teacher with each learner \&learners to learner is important and large class size may affect the proportion of students-centered method. Regarding this, Amare, (1999) indicated that the crudeness of class room is one of the critical problem of education in Ethiopian context that hindered learners follow up, learners' participation, teachers' \& learners' communication \& feed back in the classroom.

\subsubsection{Lack of materials or equipment needed to support active learning}

Sasikumar, (2018) stated that the lack of materials or equipment needed to support active learning can be a barrier to the use of some active learning strategies but certainly not all. For example, asking students to summarize in writing the material they have read or to form pairs to evaluate statements or assertions does not 
require any equipment.

\subsubsection{Students resist non-lecture approaches}

Students resist non-lecturing approaches because active learning alternatives provide a sharp contrast to the very familiar passive listening role to which they have become accustomed. With explicit instruction in how to actively participate and learn in less-traditional modes, students soon come to favor the new approaches (Sasikumar, 2018).

\section{Unit three}

\section{Research Methodology}

This chapter discussed the methodological aspects of the research, which includes research design, research method, study population, sample size and sampling techniques, data collecting instruments, validity, reliability, procedure of data collecting, methods of data analysis and ethical consideration.

\subsection{Research Approach and Design}

This study was conducted by using the mixed method approach. Because this method helps the researcher to see the issue under study both from qualitative and quantitative perspective. In addition, the method is proper to give a solution which understand and implemented by all the consumers of the research findings. Further, mixed method used to complement the weakness of one method by the strength of the other method. Quantitative research method helps to analyze a data, which was quantitative where, qualitative research used to analyze those data, which was not quantitative (Yin et al., 2004).

\subsection{Research Design}

Descriptive survey research design was used for this study. It was selected for the reason that enables the researcher to get current information about the current practice of active learning in ARPC. It is also relevant to collect detailed and a variety of information about practice of active learning. Moreover, Kothari, (2004) stated that the major purpose of descriptive survey design is the description of the state of affairs as it exists at present. Furthermore, he explained that the main characteristic of descriptive survey is that it enables the researcher to come up with what has happened or what is happening. In this study the researcher used descriptive research, to describe the qualitative and quantitative data that was gathered by different data collection method.

\subsection{Study setting}

Amhara Region Police College is the one which serves the Amhara region by producing the effective police officers for the region. The main purpose of this police college is to give different police training for police members and new police trainees. Police College has given different training for trainees based on federal and national situation. The police college is found $274 \mathrm{~km}$ from Bahir Dar and $300 \mathrm{~km}$ from Addis Ababa. In ARPC there are 206 employees.

\subsection{Population \& Sampling method}

\subsection{1. population}

In ARPC there is 31 instructors, one general director and three vice directors, $125,3^{\text {rd }}$ round regular diploma cadets. The target population that is represented in the study is Amhara Region Police College. The participants of the study were academics directors, research department heads, instructors, and $3^{\text {rd }}$ round cadets of ARPC. The researcher limited the number of participants to a more manageable number of people. 128 people were participated during the time of the study. The numbers of academics director and research department heads were 2, the numbers of participating instructors were 31 and the numbers of cadets' sample were 95.

\subsubsection{Sampling method}

The researcher selected all 31 Amhara Region police college instructors, one academic director and one research department head using purposive sampling techniques because the number is small (Kothari, 2004). The other reason, in this study, the researcher believes that those respondents may have prior knowledge and they gave insights into a particular issue related to the study area(Alston \& Bowles, 2018).

Other target population shall contain 95 cadets from $3^{\text {rd }}$ round cadets in Amhara region Police College. Simple random sampling used to select sample respondent cadets, because this method helps the researcher to give each element in the population an equal chance of getting into the sample and all choices are independent of one another and it gives each possible sample combination an equal chance of being chosen (Kothari, 2004). Both Female and male $3^{\text {rd }}$ round cadets and instructors were included. The sample sizes as under for the different strata were identified by the using Yamane formula. The formula for estimating the sample size based on 95\% confidence level need from a given population were provided (Bixley \& Yamane, 1965).

$$
\text { Sampling formula: } \mathrm{n}=\frac{N}{1+N(\mathrm{\theta}) 2}=125 \div 1+125(0.05)^{2}=95 \text { where, } \mathrm{n}=\text { Sample Size, } \mathrm{N}=\text { Total Population, e }
$$


$=$ acceptable error (i.e. with 95 confidence level, $5 \%$ margin of error) "Proportional allocation is considered most efficient and an optimal design when the cost of selecting an item is equal for each stratum, there is no difference in within-stratum variances, and the purpose of sampling happens to be to estimate the population value of some characteristic" (Kothari, 2004).

\subsection{Sources of data}

Primary data were employed in this research to gather detailed information on implementation of active learning practices and what factors hinder its implementation, in Amharic Region Police College. The primary sources of data were collected from sample respondents focusing to their attitudes towards implementation of active learning practices in Amhara Region Police College.

\subsection{Data collection instruments}

Multiple data gathering tools were used to collect data from the study area. Thus, Questionnaires, observation and semi-structured interviews were employed to gather data. So as to achieve the research objective, questionnaire, observation and interview were used as data collection instruments. A number of questions that can address the objective of the study were gathered and adapted from (Biruh, 2018).

\subsubsection{Questionnaire}

Questionnaire is widely used in educational research to obtain information about certain conditions and practices to inquire into opinions and attitudes of individuals and groups. According to Best,and Kahn (1997) questionnaire is advantageous to gather data from a number of respondents at one place which makes possible an economy of time and expense, and provides high proportion of usable responses (Brewerton \& Millward, 2001). From sample of 95 cadets and 31 instructors' quantitative data were collected using self administered questionnaires which were prepared separately for the cadets and instructors.

The questionnaires were prepared in English and Amharic language and the questionnaires have 2 sections. The first section was intended to gather background information of the instructors and cadets. The second section of the questionnaire was designed with 4 parts to gather the main data. The first part has items which help to examine instructors' and cadets' understanding of active learning. The second and third parts were about the current instructors and cadets practice of active learning and the forth part was about the challenges in implementation of active learning.

\subsubsection{Interview}

According to Kothari,(2004) interview helps the researcher to get more information and to obtain personal information about the research topic and can achieve research objectives. Interviews were employed to acquire in-depth qualitative data and data that can't be handling by questionnaires. Academic director and research department head were interviewed by using a semi structured interview guide it was prepared separately for the academic director and research department.

\subsubsection{Observation}

Observation is a process in which the investigator observes what is occurring in some real life situation. In observation, the observer can classify and record pertinent happenings according to some plan scheme. The main advantage of this method is that biases can be eliminated, if observation is done accurately and the information obtained under this method relates to what is currently happening. Observation methods occupied an important place in descriptive educational research (Kothari, 2004). Class room observation is one of the supplementary data collecting instruments. In this study the researcher assessed the practices of active learning in ARPC. Hence, there are two classrooms and a total of 8 observations were marked using structured observation conducted, to undertake descriptive study. Checklist was prepared for class room observation to obtain first hand information about the activities of instructors and cadets during teaching and learning process. The checklist is already adapted from (Taye Geressu, 2008).

\subsection{Method of data analysis}

Data analysis was done in three phases. In the first phase the quantitative data was analyzed using a quantitative approach. The collected data analysis was done in SPSS Version 24. Frequencies, percentages and means were used during the data analysis.

In the second phase the qualitative data was analyzed considering the research question, using framework coding which is a deductive approach. Frequencies, percentages, mean and descriptive statements were used to give answers for research questions. The response categories in Likert scales have a rank order.

After analysis of the quantitative and qualitative data separately, results were merged and there was a common interpretation phase to look for answers to the research questions and to yield insights for the discussion and conclusion of this study. 


\subsection{Reliability \& Validity of the Instrument}

The questionnaires and interview guides were pre-tested by Ethiopian police university students which are not members of the sample respondent to insure the reliability of these instruments and to avoid their ambiguity. According to Kothari, (2004) a measuring instrument is reliable if it provides consistent results. It is commonly used as a measure of the internal consistency or reliability of a psychometric test score for a sample of examinees. Cronbach's alpha was employed to determine the internal reliability of the questionnaire that was used in this study.

These questionnaires were given for English language expert for the validity of the data collection instruments. This was involved going through the questionnaire and interview in relation to the settled objectives and making sure that they contain all the information that can enable to answer these objectives.

\subsubsection{Reliability Instrument}

Reliability refers to the degree to which the data collection tools or analysis procedures will yield consistent findings (Saunders et al., 2009). Reliability analysis measures the internal consistency of a group of items which is used in questionnaire construction. Reliability analysis examines the homogeneity or cohesion of the items that comprise each scale. Cronbach's alpha coefficient is the most frequently used index of reliability. Cronbach's alpha coefficient is the most common way to assess reliability. a value of Cronbach's alpha coefficient above 0.70 is regarded as acceptable (Saunders et al., 2009). For the purpose of this study, the Cronbach's alpha coefficient was calculated by distributing questionnaires. The reliability of standardized test is usually expressed as scale, which measures the scale value of questions. Based on this internal consistency reliability test was conducted in Amhara Region Police College with the sample of 31 instructors and 95 cadets, and cronbach's alpha coefficient for the instrument was found as 0.816 and 0.953 respectively which is highly reliable.

Table 3. 1 Reliability test for instructor's questionnaire

\begin{tabular}{|c|c|c|c|}
\hline \multicolumn{4}{|c|}{ Case Processing Summary } \\
\hline & & $\mathrm{N}$ & $\%$ \\
\hline \multirow[t]{3}{*}{ Cases } & Valid & 31 & 100.0 \\
\hline & Excluded $^{\mathrm{a}}$ & 0 & .0 \\
\hline & Total & 31 & 100.0 \\
\hline
\end{tabular}

Source: SPSS reliability result output, 2020

Table 3. 2 Reliability test for instructor's questionnaire

\begin{tabular}{|r|r|}
\hline \multicolumn{2}{|c|}{ Reliability Statistics } \\
\hline Cronbach's Alpha & N of Items \\
\hline .816 & \\
\hline
\end{tabular}

Source: SPSS reliability result output, 2020

Table 3. 3 Reliability test for cadet's questionnaire

\begin{tabular}{|c|c|c|c|}
\hline \multicolumn{4}{|c|}{ Case Processing Summary } \\
\hline & & $\mathrm{N}$ & $\%$ \\
\hline \multirow[t]{3}{*}{ Cases } & Valid & 95 & 100.0 \\
\hline & Excluded $^{\mathrm{a}}$ & 0 & .0 \\
\hline & Total & 95 & 100.0 \\
\hline
\end{tabular}

a. Listwise deletion based on all variables in the procedure.

Source: SPSS reliability result output, 2020

Table 3. 4 Reliability test for cadet's questionnaire

\begin{tabular}{|r|r|}
\hline \multicolumn{2}{|c|}{ Reliability Statistics } \\
\hline Cronbach's Alpha & N of Items \\
\hline .953 & 111 \\
\hline
\end{tabular}

Source: SPSS reliability result output, 2020

\subsubsection{Validity of instrument}

Validity refers to the extent to which the measurement measures what is intended to measure. The instrument was designed by taking in to consideration of all items included in the questionnaires are directly derived from it and consistent with the objective of the study. Since the Questionnaire was adapted, the researcher did not test the validity of the questionnaire. 


\subsection{Ethical considerations}

In order to ensure ethical issues, first the researcher got permission from the organization and participant under the study. The researcher provided information concerning the topic, purpose, and overall benefit of the study to the participants. The researcher also made sure that participation in the study was voluntary. While collecting and analyzing, the data the name of the participants remained confidential and questionnaires were administered without interrupting the normal work place. The final report of the study was used for the purpose mentioned above. In addition to this, the final report was presented to the organization and the participants upon request.

\subsection{Dissemination of Results}

The result of the study will be submitted to Debre Markos University institution of educational and behavioral sciences and department of education. Additionally the findings of the research will be submitted to Amhara Region Police College and it is going to be presented on police conference.

\section{Unit four}

\section{Presentation, Analysis Interpretation of Data and Discussion}

This chapter deals with the presentation, analysis and interpretation of the data collected through questionnaires, observation and interviews. It consists of two parts. The first part is concerned with the description of the background personal characteristics of the respondents and the second part is concerned with the analysis of the main data.

\subsection{Background of Respondents}

The major categories of respondents involved in this study were cadets, instructors of ARPC. A total of 128 participants included in this study, 95 were cadets, 31 were instructors and two were academic director of the college and research department head of the college.

The questionnaires were administered to 95 cadets and 31 instructors. All 95 cadets and instructors have returned the questionnaire and this represents $100 \%$ response rate at all.

Table 4. 1. Background Information of Instructors

\begin{tabular}{|l|l|l|l|}
\hline Variables & Category & Frequency & Percent (\%) \\
\hline \multirow{5}{*}{ Sex } & Male & 27 & 87.1 \\
\cline { 2 - 4 } & Female & 4 & 12.9 \\
\cline { 2 - 4 } & Total & 31 & 100 \\
\hline \multirow{5}{*}{ Expe } & $18-29$ years & 3 & 9.7 \\
\cline { 2 - 4 } & $30-39$ years & 17 & 54.8 \\
\cline { 2 - 4 } & $40-49$ years & 9 & 29.0 \\
\cline { 2 - 4 } & 50 years and older & 2 & 6.5 \\
\cline { 2 - 4 } & Total & 31 & 100 \\
\hline \multirow{5}{*}{ Level of education } & less than one year & 2 & 6.5 \\
\cline { 2 - 4 } & $1-5$ years & 11 & 35.5 \\
\cline { 2 - 4 } & $6-10$ years & 8 & 25.8 \\
\cline { 2 - 4 } & More than 10 years & 10 & 32.3 \\
\cline { 2 - 4 } & Total & 31 & 100 \\
\cline { 2 - 4 } & Diploma & 3 & 9.7 \\
\cline { 2 - 4 } & Degree & 17 & 54.8 \\
\cline { 2 - 4 } & Second degree & 11 & 35.5 \\
\cline { 2 - 4 } & Total & 31 & 100 \\
\hline
\end{tabular}

The background information of instructors $(\mathrm{n}=31)$ who completed the questionnaire are summarized in the table 4.1 above. As shown in the table (27) $87.1 \%$ of the instructors who filled and returned the questioners were men and the rests (4) $12.9 \%$ were women. Concerning the educational background of instructors, 11 (35.5\%) instructors were second degree holder, 17 (54.8\%) degree and $3(9.7 \%)$ were diploma holders.

All 95 cadet respondents were the second year $3^{\text {rd }}$ round diploma cadets of ARPC. $25(26.3 \%)$ of the student respondents were women and the remaining $70(73.7 \%)$ were men.

The interviews conducted with one academic director of the college and one from research department head. The academic director and research department head were men and they qualified with second degree.

\subsection{Analysis of the main data}

This part deals with the analysis of the main data obtained from questionnaires, observation and interviews. In line with the basic research questions formulated in the introduction part, major emphasis given on the cadet's and instructor's understanding of active learning, on extent of current practices of active learning and on 
identifying of main factors affecting the practice of active learning in the Amhara Police College.

The quantitative data which were collected through the questionnaires presented with the help of tables with five Likert scale and merged in to three Likert scales which means very high and high merged into high, very low and low merged into low and moderate stand on as it is. The results of the interviews and observation analyzed qualitatively and presented in statement forms.

\subsubsection{Instructors and cadets Understanding of Active Learning Method}

Teachers' understanding of active learning highly influences on implementation of active learning either positively or negatively. Additionally the understanding of students also affects on implementation of active learning ((Mebratu \& Woldemariam, 2018)).

The analysis and interpretation of instructors' and cadets' understanding of active learning method, a five point Likert scale which arranges from very high to very low used. Scoring made by assigning values of 5,4,3,2 and 1 for the very high, high, moderate, low and very low.

\subsubsection{Instructor Understanding of Active Learning Method}

Table 4. 2 Responded by instructors about understanding of active learning

\begin{tabular}{|c|c|c|c|c|c|c|c|c|c|c|c|c|}
\hline \multirow{3}{*}{ No } & \multirow{3}{*}{ Item } & \multicolumn{10}{|c|}{ Number of respondents and percentage } & \multirow[t]{3}{*}{$\mathrm{M}$} \\
\hline & & \multicolumn{2}{|c|}{5} & \multicolumn{2}{|c|}{4} & \multicolumn{2}{|c|}{3} & \multicolumn{2}{|c|}{2} & \multicolumn{2}{|c|}{1} & \\
\hline & & $\mathrm{F}$ & $\%$ & $\mathrm{~F}$ & $\%$ & $\mathrm{~F}$ & $\%$ & $\mathrm{~F}$ & $\%$ & $\mathrm{~F}$ & $\%$ & \\
\hline 1 & $\begin{array}{l}\text { Active learning enables learners to } \\
\text { understand the ways of solving } \\
\text { problems. }\end{array}$ & 15 & 48.4 & 14 & 45.2 & 1 & 3.2 & 1 & 3.2 & - & & 4.35 \\
\hline 2 & $\begin{array}{l}\text { Active learning creates a democratic } \\
\text { relationship between the teachers and } \\
\text { the students. }\end{array}$ & 13 & 41.9 & 11 & 35.5 & 41 & 12.9 & 3 & 9.7 & - & & 4.10 \\
\hline 3 & $\begin{array}{l}\text { Interaction and active participation of } \\
\text { cadets is important for the effectiveness } \\
\text { and quality of education. }\end{array}$ & 22 & 71 & 6 & 19.4 & 3 & 9.7 & - & & - & & 4.61 \\
\hline 4 & $\begin{array}{l}\text { Active learning methods encourage } \\
\text { students self directed learning and } \\
\text { problem solving skills. }\end{array}$ & 17 & 54.8 & 9 & 29 & 3 & 9.7 & 1 & 3.2 & 1 & 3.25 & 4.29 \\
\hline 5 & $\begin{array}{l}\text { Active learning creates the } \\
\text { opportunities to share experiences and } \\
\text { encourage friendship among the } \\
\text { students. }\end{array}$ & 19 & 61.3 & 10 & 32.3 & 2 & 6.5 & - & & - & & 4.55 \\
\hline 6 & $\begin{array}{l}\text { Active learning enhances self } \\
\text { confidence and independent learning of } \\
\text { students. }\end{array}$ & 17 & 54.8 & 12 & 38.7 & 1 & 3.2 & 1 & 3.2 & - & & 4.39 \\
\hline 7 & $\begin{array}{l}\text { Students learn best when they actively } \\
\text { involve and practice. }\end{array}$ & 17 & 54.8 & 13 & 41.9 & 1 & 3.2 & - & & - & & 4.48 \\
\hline 8 & $\begin{array}{l}\text { Lectures are the most valuable teaching } \\
\text { method. }\end{array}$ & 3 & 9.7 & 10 & 32.3 & 14 & 45.2 & - & & 4 & 12.9 & 3.26 \\
\hline 9 & $\begin{array}{l}\text { Group work discourages students on } \\
\text { basic police sciences insight }\end{array}$ & 2 & 6.5 & - & - & 8 & 25.8 & 8 & 25.8 & 13 & 41.9 & 2.03 \\
\hline 10 & $\begin{array}{l}\text { Students should engage as fine listeners } \\
\text { during learning. }\end{array}$ & 1 & 3.2 & 1 & 3.2 & 5 & 16.2 & 9 & 29 & 15 & 48.4 & 1.84 \\
\hline 11 & $\begin{array}{l}\text { Students should be encouraged to make } \\
\text { decisions about the what, how and } \\
\text { when of learning. }\end{array}$ & 7 & 22.6 & 4 & 12.9 & 12 & 38.7 & 4 & 12.9 & 4 & 12.9 & 3.19 \\
\hline 12 & $\begin{array}{l}\text { The quality of education can be } \\
\text { improved if teachers shift their } \\
\text { instruction from lecture method to } \\
\text { active learning approaches. }\end{array}$ & 10 & 32.3 & 12 & 38.7 & 3 & 9.7 & 4 & 12.9 & 2 & 6.5 & 3.77 \\
\hline \multicolumn{12}{|c|}{ Grand mean } & 3.74 \\
\hline
\end{tabular}

$5=$ Very high $4=$ High $3=$ Moderate $2=$ Low $1=$ Very low $\mathrm{M}=$ Mean $\mathrm{F}=$ Frequency

As depicted in table 4.2., all the statements appeared were positive statements about the assumptions of active learning except the statements appeared in the item no 8,9 and 10 .

$93.6 \%$ of the respondents have high understanding to statements in item 1, which say "Active learning enables learners to understand the ways of solving problems."

$77.4 \%$ of the respondents have high understanding to statements in item 2, which say "Active learning 
creates a democratic relationship between the teachers and the students" $90.4 \%$ of the respondents have high understanding to statements in item 3, which say "Interaction and active participation of students is one of the most important for the effectiveness and quality of education."

From the participants, $83.8 \%$ of the respondents have high understanding to statements in item 4 , which say "Active learning methods encourage students' self-directed learning and problem solving skills".

From the participants, $93.6 \%$ of the respondents have high understanding to statements in item 5, which say "Active learning creates the opportunities to share experiences and encourage friendship among the students".

Additionally, high proportion of instructors (93.5\%) and (96.7\%) showed their understanding by high to those items in no 6 and 7 of table 4.2., which says "Active learning enhances self-confidence and independent learning of students" and "Students learn best when they actively involve and practice".

Item 8, which say, "Lectures are the most valuable teaching method", were high by $42 \%$ of the respondents and $12.9 \%$ of respondents were given their responses were low. The rest $45.2 \%$ of the respondents remained neutral with this idea.

Item 9 states "Group work discourages students on basic police sciences insight". For this item, 6.5\% of instructor respondents showed high since $67.7 \%$ of the respondent expressed their understanding low and other $25.8 \%$ of respondent were neutral idea with the statement.

From the participants, $77.4 \%$ of the respondents have low understanding to statements in item 10 , which say "Students should engage as fine listeners during learning."

In item number 8,9 and 10 question were negative statements. So the grand mean of respondent was 2.3. This showed that the instructor understanding about active learning was positive.

Item 11 states "Students should be encouraged to make decisions about the what, how and when of learning." For this item, $35.5 \%$ of instructor respondents showed high, since $25.8 \%$ of the respondent expressed their understanding low and other $38.7 \%$ of respondent were neutral idea with the statement.

Statements in item no 11 were also high by $71 \%$ of the respondents. This indicated that majority of the instructors agreed with the "The quality of education improved if teachers shift their instruction from lecture method to active learning approaches".

The grand mean value of instructor respondents is 4.2 except the negative statements of item no. 8, 9 and 10 . It shows that high understanding. This implies majority of the instructors have supposed active learning positively.

4.2.1.2. understanding of cadets about Active Learning Methodology

12 items presented to cadets to find out their understanding of active learning and their responses are summarized in table 4.3 below.

Table 4. 3 Responded by cadets about understanding of active learning

\begin{tabular}{|c|c|c|c|c|c|c|c|c|c|c|c|c|}
\hline \multirow{3}{*}{ No } & \multirow{3}{*}{ Item } & \multicolumn{10}{|c|}{ Number of respondents and percentage } & \multirow[b]{3}{*}{ M } \\
\hline & & \multicolumn{2}{|c|}{5} & \multicolumn{2}{|c|}{4} & \multicolumn{2}{|c|}{3} & \multicolumn{2}{|c|}{2} & \multicolumn{2}{|c|}{1} & \\
\hline & & $\mathrm{F}$ & $\%$ & $\mathrm{~F}$ & $\%$ & $\mathrm{~F}$ & $\%$ & $\mathrm{~F}$ & $\%$ & $\mathrm{~F}$ & $\%$ & \\
\hline 1 & $\begin{array}{l}\text { Active learning enables students } \\
\text { understand what they are learning }\end{array}$ & 3 & 3.2 & 45 & 47.4 & 39 & 41.1 & 7 & 7.4 & 1 & 1.1 & 3.44 \\
\hline 2 & $\begin{array}{l}\text { Active learning provides better } \\
\text { confidence for students to use and } \\
\text { improve their problem solving skill }\end{array}$ & 11 & 11.6 & 30 & 31.6 & 35 & 36.8 & 16 & 16.8 & 3 & 3.2 & 3.31 \\
\hline 3 & $\begin{array}{l}\text { Active learning involves a democratic } \\
\text { relationship between the teacher and } \\
\text { the student. }\end{array}$ & 14 & 14.7 & 42 & 44.2 & 30 & 31.6 & 6 & 6.3 & 3 & 3.2 & 3.61 \\
\hline 4 & $\begin{array}{l}\text { Active learning is not an appropriate } \\
\text { method to be practiced in Amhara } \\
\text { Region police college }\end{array}$ & 6 & 6.3 & 16 & 16.8 & 25 & 26.3 & 25 & 26.3 & 23 & 24.2 & 2.54 \\
\hline 5 & $\begin{array}{l}\text { Active learning method creates } \\
\text { problems to classroom management } \\
\text { and is not advisable to use it }\end{array}$ & 7 & 7.4 & 15 & 15.8 & 20 & 21.1 & 29 & 30.5 & 24 & 25.3 & 2.49 \\
\hline 6 & $\begin{array}{l}\text { Active learning method creates a } \\
\text { heavy load on the part of the student, } \\
\text { and it is difficult to practice. }\end{array}$ & 10 & 10.5 & 14 & 14.7 & 29 & 30.5 & 20 & 21.1 & 22 & 23.2 & 2.68 \\
\hline 7 & $\begin{array}{l}\text { Active learning methods consume } \\
\text { much of teachers' time and results in } \\
\text { difficulty to cover the content. }\end{array}$ & 8 & 8.4 & 16 & 16.8 & 25 & 26.3 & 22 & 23.2 & 24 & 25.3 & 2.6 \\
\hline
\end{tabular}




\begin{tabular}{|c|c|c|c|c|c|c|c|c|c|c|c|c|}
\hline \multirow{3}{*}{ No } & \multirow{3}{*}{ Item } & \multicolumn{10}{|c|}{ Number of respondents and percentage } & \multirow[b]{3}{*}{ M } \\
\hline & & \multicolumn{2}{|c|}{5} & \multicolumn{2}{|c|}{4} & \multicolumn{2}{|c|}{3} & \multicolumn{2}{|c|}{2} & \multicolumn{2}{|c|}{1} & \\
\hline & & $\mathrm{F}$ & $\%$ & $F$ & $\%$ & $F$ & $\%$ & $\mathrm{~F}$ & $\%$ & $\mathrm{~F}$ & $\%$ & \\
\hline 8 & $\begin{array}{l}\text { Active learning methods related to the } \\
\text { objectives of the lessons and the } \\
\text { activities given are good to make the } \\
\text { classroom teaching learning } \\
\text { interesting }\end{array}$ & 15 & 15.8 & 22 & 23.2 & 34 & 35.8 & 17 & 17.9 & 7 & 7.4 & 3.22 \\
\hline 9 & $\begin{array}{l}\text { It seems that your teachers have good } \\
\text { interest to let you work activities in the } \\
\text { classroom than presenting the lesson } \\
\text { themselves. }\end{array}$ & 13 & 13.7 & 42 & 44.2 & 23 & 24.2 & 12 & 12.6 & 5 & 5.3 & 3.48 \\
\hline 10 & $\begin{array}{l}\text { Most of the students in your class feel } \\
\text { happy when the teacher gives you } \\
\text { some activities to be done and } \\
\text { presented soon. }\end{array}$ & 8 & 8.4 & 32 & 33.7 & 28 & 29.5 & 16 & 16.8 & 11 & 11.6 & 3.1 \\
\hline 11 & $\begin{array}{l}\text { You and your friends think that when } \\
\text { you do activities by yourself you learn } \\
\text { best than simply listening to your } \\
\text { teacher }\end{array}$ & 8 & 8.4 & 24 & 25.3 & 25 & 26.3 & 30 & 31.6 & 8 & 8.4 & 2.93 \\
\hline 12 & $\begin{array}{l}\text { In general we can say that currently } \\
\text { active learning is in practice in your } \\
\text { classroom. }\end{array}$ & 9 & 9.5 & 26 & 27.4 & 34 & 35.8 & 17 & 17.9 & 9 & 9.5 & 3.09 \\
\hline \multicolumn{12}{|c|}{ Grand mean } & 3.04 \\
\hline
\end{tabular}

$5=$ Very high $4=$ High $3=$ Moderate $2=$ Low $1=$ Very low $\mathrm{M}=$ Mean $\mathrm{F}=$ Frequency

As described in the above table 4.3, all of the statements appeared were positive statements about the assumptions of active learning except the statements become visible in item no 5, 6 and 7 .

As indicated in the table, high percentage $(50.6 \%, 43.2 \%, 58.9 \%, 39 \%, 57.9 \%, 42.1 \%$ and $36.9 \%)$ of the cadet respondents showed high with the statements in item no $1,2,3,8,9,10$ and 12 of table 4.3 , which have a positive statement about the assumption of active learning.

This shows that cadets have positive understanding with the concepts that active learning enables students understand what they are learning, Active learning provides better confidence for students to use and improve their problem solving skill, and Active learning involves a democratic relationship between the teacher and the student.

On the other hand, majority of the cadet respondents showed their low understanding to the item number 4 and 11 of table 4.3 item 4 which states, "Active learning is not a proper method practiced in Amhara Region Police College", was low by $50.5 \%$ and $40 \%$ of the respondents.

Item 5, 6 and item 7, which says "Active learning method creates problems to classroom management and is not advisable to use it", "Active learning method creates a heavy load on the part of the student, and it is difficult to practice" and "Active learning methods consume much of teachers' time and results in difficulty to cover the content" were also low by $55.8 \%, 44.3 \%$ and $48.7 \%$ of the respondents. But the above item no.5, 6 and 7 questions have negative statement about understanding of active learning. So, the responses of cadets showed that they have perceived active learning positively.

The grand mean value of cadet respondents in item no. $1,2,3,4.8,9,10,11$ and 12 were $3.2 \%$. Like the instructor respondents, majority of the cadets had a positive understanding about active learning. And also the mean of negative statement that in item no. 5, 6 and 7 was 2.59. This means that understanding of cadets about active learning was positive.

The interview report also approved that most of the instructors and cadets mostly had a positive perception of active learning, even if some of them had some misconceptions about it. The data obtained through interview with research department head and academics director indicated that most instructors have seen active learning method as a best method which enhances cadets learning and help the teaching learning process in a best way. My interviewees mentioned that active learning method or student centered approach is a good strategy which enables cadets to acquire the required knowledge, to develop skills and necessary competencies than a teacher centered approach.

The interviews also showed that instructors think as it was very hard to practice active learning method in ARPC because it wasn't the tradition in our college. In the open-ended question that was presented for instructors were also indicated that active learning creates a heavy load on both instructors and cadets' side and use time and resource intensively and it needs special skills to practice, which leads them to think as it is very 
difficult to carry out active learning methodologies in ARPC. The interview with the academic director of the college also showed that most of the instructors have a positive perception of active learning but some don't have positive understanding on active learning methodologies. Additionally, the academic director also indicated that different regular courses, trainings and seminars designed and organized to raise the awareness of ARPC instructors on active learning methodologies.

The academic director of the college expressed his judgment about the assumption of instructors and cadets towards active learning approach by saying:
"Most of our instructors and cadets are familiar with the concept of active learning.
They know that our education and training policy encouraged carrying out active learning method which is scientifically supported strategy to improve the quality education. Despite their good understanding of active learning, majority of our teachers and students tend to use the traditional method because they have not brought attitudinal changes yet". (AD, 2020).

The research department head of the college also expressed his judgment about the understanding of instructors and cadets towards active learning approach by saying:

"Both instructors and cadets' attitudes are low. The reason is that there is no enough training, research-based training, and instructors are follow teacher-centered approaches." (RD,2020).

In consistent this research finding, the study revealed that most instructors and cadets mostly have a positive perception towards active learning method. This shows that cadets and instructors could be a good implementer if they committed to carry out active learning method and if conducive, environment will create in the college.

The main target here is that there is a strong relationship between instructors and cadets' understanding and their effort to practice active learning. Therefore, to carry out active learning, proper measures taken to bring full attitudinal change in cadets and instructors by filling the gap on their perception of how to practice active learning.

\subsubsection{Practices of Active Learning Method in Amhara Region Police College}

The main goal of this study was to assess extent of practice of active learning by instructors and cadets. To meet this, instructors and cadets were asked about the current practice of their roles during active learning and extent of their practice of different active learning techniques and their responses discussed in this section separately.

\subsubsection{Analysis of data obtained on the instructors and cadets in the current practices of active learning method}

To find out instructors and cadets current practice of active learning in ARPC, 6 items question presented to cadets and another different 7 items presented to teachers and their responses summarize in separate tables 4.4 below.

Table 4. 4 Responses of cadet's regarding to instructors and students practice in using active learning $5=$ Very high, 4= High, 3= Moderate, $2=$ Low, $1=$ Very low, $M=$ Mean, $F=$ Frequency

\begin{tabular}{|c|c|c|c|c|c|c|c|c|c|c|c|c|}
\hline \multirow[t]{3}{*}{ No } & \multirow{3}{*}{ Item } & \multicolumn{10}{|c|}{ Number of respondent } & \multirow[t]{3}{*}{ M } \\
\hline & & \multicolumn{2}{|c|}{5} & \multicolumn{2}{|r|}{4} & \multicolumn{2}{|c|}{3} & \multicolumn{2}{|c|}{2} & \multicolumn{2}{|c|}{1} & \\
\hline & & $\mathrm{F}$ & $\%$ & $\mathrm{~F}$ & $\%$ & $\mathrm{~F}$ & $\%$ & $\mathrm{~F}$ & $\%$ & $\mathrm{~F}$ & $\%$ & \\
\hline 1 & $\begin{array}{l}\text { It seems to you that your teachers have } \\
\text { good knowledge of teaching students } \\
\text { involving them in active learning } \\
\text { methods }\end{array}$ & 5 & 5.3 & 30 & 31.6 & 44 & 46.3 & 8 & 8.4 & 8 & 8.4 & 3.14 \\
\hline 2 & $\begin{array}{l}\text { Your teachers regularly motivate you } \\
\text { to ask questions and to practice } \\
\text { different activities in the class room }\end{array}$ & 9 & 9.5 & 35 & 36.8 & 34 & 35.8 & 13 & 13.7 & 4 & 4.2 & 3.34 \\
\hline 3 & $\begin{array}{l}\text { Your teachers encourage participation } \\
\text { of students in different activities }\end{array}$ & 3 & 3.2 & 39 & 41.1 & 30 & 31.6 & 19 & 20 & 4 & 4.2 & 3.12 \\
\hline 4 & $\begin{array}{l}\text { Students frequently discuss in pairs or } \\
\text { groups in your classes }\end{array}$ & 24 & 25.3 & 40 & 42.1 & 19 & 20 & 9 & 9.5 & 3 & 3.2 & 3.77 \\
\hline 5 & $\begin{array}{l}\text { Your teacher arranges students for } \\
\text { different classroom activities like } \\
\text { discussion, debating, presentation, } \\
\text { peer-teaching, group work }\end{array}$ & 8 & 8.4 & 38 & 40 & 25 & 26.3 & 17 & 17.9 & 7 & 7.4 & 3.24 \\
\hline
\end{tabular}




\begin{tabular}{|c|c|c|c|c|c|c|c|c|c|c|c|c|}
\hline \multirow[t]{3}{*}{ No } & \multirow{3}{*}{ Item } & \multicolumn{10}{|c|}{ Number of respondent } & \multirow[t]{3}{*}{$\mathrm{M}$} \\
\hline & & \multicolumn{2}{|r|}{5} & \multicolumn{2}{|r|}{4} & \multicolumn{2}{|c|}{3} & \multicolumn{2}{|c|}{2} & \multicolumn{2}{|r|}{1} & \\
\hline & & $\mathrm{F}$ & $\%$ & $\mathrm{~F}$ & $\%$ & $F$ & $\%$ & $F$ & $\%$ & $F$ & $\%$ & \\
\hline 6 & $\begin{array}{l}\text { Teachers come to the classroom } \\
\text { having different teaching materials } \\
\text { like Videos, PowerPoint presentations, } \\
\text { Models etc to motivate their students } \\
\text { to the subject. }\end{array}$ & 4 & 4.2 & 10 & 10.5 & 26 & 27.4 & 28 & 29.5 & 27 & 28.4 & 2.33 \\
\hline \multicolumn{12}{|c|}{ Grand mean } & 3.16 \\
\hline
\end{tabular}

As it presented in table 4.4, which summarize the result of data from cadets' questionnaire, the first item says "It seems to you that your teachers have good knowledge of teaching students involving them in active learning methods". About $5.3 \%$ and $31.6 \%$ of respondents showed their high to the item. On the other hand, $8.4 \%$ of the respondents showed their low about the knowledge of their instructor in active learning. The rest $46.3 \%$ of the respondents were moderate to this item. This shows that most of the cadets did not know that their instructors have good knowledge of teaching using active learning methods or not.

However, the data obtained through interview with the academic director shows that many instructors do not have enough knowledge and required skills to effectively exercise active learning methods in the class room because instructors have not adequate trainings on teaching methodologies.

The second item states "Your teachers regularly motivate students to ask questions and to practice different activities in the class room". Majority of the cadets supported this idea. $46.3 \%$ of the respondents showed high. $17.9 \%$ of the respondents were low with this idea. Similarly, the third item, which says "Your teachers encourage participation of students in different activities", was also supported by majority of the respondents. This implies that instructors are trying to actively involve cadets in the teaching learning process.

For item no. 3, 4 and 5 which says, "Your teachers encourage participation of students in different activities", "Students often discuss in pairs or groups in your classes" and "Your teacher arranges students for different classroom activities like discussion, debating, presentation, peer-teaching, group work" cadets replied their answer as high by $44.3 \%, 67.4 \%$ and $48.8 \%$ of

In item no. 6 on table $4.4,57.9 \%$ of cadets gave their response for the question "Teachers come to the classroom having different teaching materials like Videos, PowerPoint presentations, models etc to motivate their students to the subject" was low. This imply that majority of ARPC instructor do not use teaching aid material during their teaching learning process.

Table 4. 5 Responses of instructor's regarding to instructors on the current practice of active learning $\mathrm{A}=$ Always, $\mathrm{Fq}=$ frequently, $\mathrm{S}=$ sometimes, $\mathrm{R}=$ rarely, $\mathrm{NA}=$ Not at all, $\mathrm{M}=$ Mean, $\mathrm{F}=$ Frequency

\begin{tabular}{|c|c|c|c|c|c|c|c|c|c|c|c|c|}
\hline \multirow[t]{3}{*}{$\mathrm{N}$} & \multirow[t]{3}{*}{ Teaching practices } & \multicolumn{10}{|c|}{ Number of respondents and percentage } & \multirow[t]{3}{*}{$\mathrm{M}$} \\
\hline & & \multicolumn{2}{|l|}{$\mathrm{A}$} & \multicolumn{2}{|c|}{$\mathrm{Fq}$} & \multicolumn{2}{|c|}{$\mathrm{S}$} & \multicolumn{2}{|c|}{$\mathrm{R}$} & \multicolumn{2}{|c|}{$\mathrm{N} \mathrm{A}$} & \\
\hline & & $\mathrm{F}$ & $\%$ & $\mathrm{~F}$ & $\%$ & $\mathrm{~F}$ & $\%$ & $\mathrm{~F}$ & $\%$ & $\mathrm{~F}$ & $\%$ & \\
\hline 1 & $\begin{array}{l}\text { Arranging students for different classroom } \\
\text { activities }\end{array}$ & 10 & 32.3 & 12 & 38.7 & 6 & 19.4 & 1 & 3.2 & 2 & 6.5 & 3.87 \\
\hline 2 & $\begin{array}{l}\text { Encouraging students to ask questions and } \\
\text { become actively participate in the } \\
\text { classroom }\end{array}$ & 14 & 45.2 & 13 & 41.9 & 3 & 9.7 & - & - & 1 & 3.2 & 4.26 \\
\hline 3 & $\begin{array}{l}\text { Invite students to reflect their idea on the } \\
\text { daily lesson and on the learning process } \\
\text { itself }\end{array}$ & 9 & 29 & 16 & 51.6 & 3 & 9.7 & 2 & 6.5 & 1 & 3.2 & 3.97 \\
\hline 4 & Give constructive feedbacks for students & 14 & 45.2 & 8 & 25.8 & 6 & 19.4 & 2 & 6.5 & 1 & 3.2 & 4.03 \\
\hline 5 & $\begin{array}{l}\text { Create activities that require higher order } \\
\text { thinking and critical thinking skills }\end{array}$ & 7 & 22.6 & 12 & 38.7 & 8 & 25.8 & 3 & 9.7 & 1 & 3.2 & 3.68 \\
\hline 6 & $\begin{array}{l}\text { Associating the classroom lesson with the } \\
\text { real life experience. }\end{array}$ & 13 & 41.9 & 10 & 32.3 & 6 & 19.4 & 2 & 6.5 & - & - & 4.10 \\
\hline 7 & Using students as resources. & 13 & 41.9 & 9 & 29 & 7 & 22.6 & 1 & 3.2 & 1 & 3.2 & 4.03 \\
\hline \multicolumn{2}{|c|}{ Grand mean } & & & & & & & & & & & 3.99 \\
\hline
\end{tabular}

Similarly the data obtained from the instructors' questionnaire also shows a similar finding. As indicated in table 4.5 above, Teachers asked how often they urge their students to ask questions and become actively take part in the class room and arranging students for different classroom activities.

Majority of the instructor respondents were often encouraging students to ask questions and become actively participate in the classroom. About $45.2 \%$ and $41.9 \%$ of respondents replied "always" and "often respectively. Only $9.7 \%$ of the respondents replied rarely and not at all for the item and for the second question which says "Arranging students for different classroom activities", had 71\% of instructor respondents replied 
always and frequently. This implies that in ARPC instructor sometimes arrange their students for different class activities'.

On the other hand, the data gained from Tables 4.5 item no $4,5,6$ and 7 , show that $80.6 \%, 71 \%, 61.3 \%$, 74.2 and $70.9 \%$. It is clear from this that the ARPC instructors were at commencement of active learning in their class but it was not much satisfactory. The grand mean of students' and instructors response was 3.16 and 3.99 respectively. This shows that teachers and students were trying to practice active learning method but the extent of their practice was not that much satisfactory.

Interviews with research department head revealed that instructors tried to discharge their roles to exercise active learning methods only sometimes. They are regularly using traditional lecture method and not practicing different active learning strategies regularly for different reasons that will be discussed in the next section of this chapter.

Table 4. 6. Class observation on the current practice of active learning in class room

\begin{tabular}{|l|l|l|l|l|l|}
\hline \multirow{2}{*}{ No. Item } & \multicolumn{2}{|c|}{ yes } & \multicolumn{2}{c|}{ No } \\
\cline { 3 - 6 } & & Number of observation & \multicolumn{2}{l|}{ Number of observation } \\
\cline { 3 - 6 } & & F & F & F & $\%$ \\
\hline 1 & Is there enough sitting space for all students? & - & 25 & 6 & 75 \\
\hline 2 & $\begin{array}{l}\text { Is the classroom arrangement arranged to } \\
\text { facilitate active learning? }\end{array}$ & 2 & & & \\
\hline 3 & Is the class size appropriate? & 3 & 37.5 & 5 & 62.5 \\
\hline 4 & Is there group work activity? & 5 & 62.5 & 3 & 37.5 \\
\hline
\end{tabular}

As we understand from the above table 4.6, there were two classrooms and the researcher observed 8 times in the classes, the data obtained from classroom observation showed that the classroom condition and seating arrangement is not suitable to implement active learning. One major problem observed in the classroom is the arrangement of the classes. Majority $(75 \%)$ of the observation result indicates that the classroom arrangement is not arranged to facilitate active learning. The arrangement of the classroom did not showed the required condition for active learning practices.

Table 4. 7 Class observation in instructor's activity on the current practice of active learning

\begin{tabular}{|c|c|c|c|c|c|}
\hline \multirow{3}{*}{ No. } & \multirow{3}{*}{ Item } & \multicolumn{2}{|c|}{ yes } & \multicolumn{2}{|c|}{ No } \\
\hline & & \multicolumn{2}{|c|}{$\begin{array}{l}\text { Number } \\
\text { observation }\end{array}$} & \multicolumn{2}{|c|}{$\begin{array}{l}\text { Number } \\
\text { observation }\end{array}$} \\
\hline & & $\mathrm{F}$ & $\%$ & $\mathrm{~F}$ & $\%$ \\
\hline 1 & Arranging students for different classroom activity & 3 & 37.5 & 5 & 62.5 \\
\hline 2 & $\begin{array}{l}\text { Using different instructional methods to implement active } \\
\text { learning }\end{array}$ & & & 8 & 100 \\
\hline 3 & Encouraging students to become active participant & 2 & 25 & 6 & 75 \\
\hline 4 & $\begin{array}{l}\text { Create activities that require higher order thinking and } \\
\text { critical thinking skills }\end{array}$ & 1 & 12.5 & 7 & 87.5 \\
\hline
\end{tabular}

In table 4.7 above, the classroom observation result showed number of the activities expected to be practiced by the instructors were not observed. For case, $100 \%$ of the observed classes, instructors did not showed the use of different instructional methods to implement active learning in the classroom. In the open ended questionnaire that was present for instructors explained them as, some of the instructors confirmed that applying all the activities in classroom is difficult. This showed that the instructors implement teacher centered approach to teaching. The reasons for not doing the activities stated in table 4.7 was lack of training on active learning and classroom conditions such as large class size.

\subsubsection{Types of active learning methods currently practice in Amhara Region Police college}

Instructors and cadets were also asked about extent of their practice of different active learning techniques. Common instructional techniques presented for respondents to show how often they employed each technique by saying always, often, sometimes, rarely and not at all. 
Table 4. 8 Responses of instructor's about understands on their practice of different active learning techniques in the classroom

$\mathrm{A}=$ Always, $\mathrm{Fq}=$ frequently, $\mathrm{S}=$ sometimes, $\mathrm{R}=$ rarely, $\mathrm{NA}=$ Not at all, $\mathrm{M}=$ Mean, $\mathrm{F}=$ Frequency

\begin{tabular}{|c|c|c|c|c|c|c|c|c|c|c|c|c|}
\hline \multirow{3}{*}{ No. } & \multirow{3}{*}{ Teaching techniques } & \multicolumn{10}{|c|}{ How often you engaged these techniques } & \multirow[t]{3}{*}{$\mathrm{M}$} \\
\hline & & \multicolumn{2}{|r|}{ A } & \multicolumn{2}{|c|}{$\mathrm{Fq}$} & \multicolumn{2}{|c|}{$\mathrm{S}$} & \multicolumn{2}{|c|}{$\mathrm{R}$} & \multicolumn{2}{|c|}{ NA } & \\
\hline & & $\mathrm{F}$ & $\%$ & $\mathrm{~F}$ & $\%$ & $\mathrm{~F}$ & $\%$ & $\mathrm{~F}$ & $\%$ & $\mathrm{~F}$ & $\%$ & \\
\hline 1 & Lecture & 7 & 22.6 & 10 & 32.3 & 11 & 35.5 & 2 & 6.5 & 1 & 3.2 & 3.65 \\
\hline 2 & Group works & 8 & 25.8 & 15 & 48.4 & 8 & 25.8 & - & - & - & - & 4.00 \\
\hline 3 & Question and Answer & 7 & 22.6 & 9 & 29 & 11 & 35.5 & 3 & 9.7 & 1 & 3.2 & 3.58 \\
\hline 4 & Demonstration & 3 & 9.7 & 4 & 12.9 & 12 & 38.7 & 10 & 32.3 & 2 & 6.5 & 2.87 \\
\hline 5 & Problem solving & 3 & 9.7 & 4 & 12.9 & 13 & 41.9 & 8 & 41.9 & 3 & 9.7 & 2.87 \\
\hline 6 & Peer teaching & 3 & 9.7 & 7 & 22.6 & 7 & 22.6 & 8 & 25.8 & 6 & 19.4 & 2.77 \\
\hline 7 & Brainstorming & 2 & 6.5 & 12 & 38.7 & 7 & 22.6 & 8 & 25.8 & 2 & 6.5 & 3.13 \\
\hline 8 & Role playing & 3 & 9.7 & 10 & 32.3 & 12 & 38.7 & 5 & 16.1 & 1 & 3.2 & 3.29 \\
\hline 9 & Individual assignments/ home works & 4 & 12.9 & 6 & 19.4 & 5 & 16.1 & 11 & 35.5 & 5 & 16.1 & 2.77 \\
\hline 10 & Case study & - & - & 7 & 22.6 & 8 & 25.8 & 11 & 35.5 & 5 & 16.1 & 2.65 \\
\hline 11 & Practice on real situations & 2 & 6.5 & 10 & 32.3 & 9 & 29 & 7 & 22.6 & 3 & 9.7 & 3.03 \\
\hline Gra & mean & & & & & & & & & & & 3.14 \\
\hline
\end{tabular}

Instructors asked to show how often they had taken up different active learning techniques in their teaching. From the analysis of instructors' response (Table 4.8), lecture, group works and question and answer were found the most commonly used learning strategy that had been always used by $22.6 \%, 25.8 \%$ and $22.6 \%$ and they used those techniques frequently by $32.3 \%, 48.4 \%$ and $29 \%$. The mean value of lecture, group works $\&$ question and answer was 3.65, 4.00 and 3.58 respectively. This shows that in ARPC those three teaching techniques employed.

Other teaching techniques that listed in the table above except the first three teaching techniques, those listed in item no. 4,5,6,7,8,9,10 and 11 were sometimes employed by ARPC instructors.

The grand mean of the instructor responses was 3.14, which shows that the instructors were utilizing different active learning techniques sometimes.

Table 4. 9 Responses of cadet's about understands on their practice of different active learning techniques in the classroom

$\mathrm{A}=$ Always, $\mathrm{Fq}=$ frequently, $\mathrm{S}=$ sometimes, $\mathrm{R}=$ rarely, $\mathrm{NA}=$ Not at all, $\mathrm{M}=$ Mean, $\mathrm{F}=$ Frequency

\begin{tabular}{|c|c|c|c|c|c|c|c|c|c|c|c|c|}
\hline \multirow[t]{3}{*}{ No. } & \multirow[t]{3}{*}{ Teaching techniques } & \multicolumn{10}{|c|}{ How often you engaged these techniques } & \multirow[t]{3}{*}{ M } \\
\hline & & \multicolumn{2}{|c|}{ A } & \multicolumn{2}{|c|}{$\mathrm{Fq}$} & \multicolumn{2}{|c|}{$\mathrm{S}$} & \multicolumn{2}{|c|}{$\mathrm{R}$} & \multicolumn{2}{|c|}{ NA } & \\
\hline & & $F$ & $\%$ & $F$ & $\%$ & $F$ & $\%$ & $F$ & $\%$ & $\mathrm{~F}$ & $\%$ & \\
\hline 1 & Lecture & 23 & 24.2 & 32 & 33.7 & 28 & 29.5 & 11 & 11.6 & 1 & 1.1 & 3.68 \\
\hline 2 & Group works & 28 & 29.5 & 42 & 44.2 & 19 & 20 & 5 & 5.3 & 1 & 1.1 & 3.95 \\
\hline 3 & Question and Answer & 10 & 10.5 & 27 & 28.4 & 30 & 31.6 & 17 & 17.9 & 11 & 11.6 & 3.08 \\
\hline 4 & Demonstration & 2 & 2.1 & 9 & 9.5 & 25 & 26.3 & 24 & 25.3 & 35 & 36.8 & 2.14 \\
\hline 5 & Problem solving & 4 & 4.2 & 13 & 13.7 & 22 & 23.2 & 34 & 35.8 & 22 & 23.2 & 2.4 \\
\hline 6 & Peer teaching & 8 & 8.4 & 21 & 22.1 & 35 & 36.8 & 20 & 21.1 & 11 & 11.6 & 2.94 \\
\hline 7 & Brainstorming & 4 & 4.2 & 13 & 13.7 & 37 & 38.9 & 17 & 17.9 & 24 & 25.3 & 2.53 \\
\hline 8 & Role playing & 6 & 6.3 & 34 & 35.8 & 31 & 32.6 & 19 & 20 & 5 & 5.3 & 3.17 \\
\hline 9 & Individual assignments/ home works & 3 & 3.2 & 11 & 11.6 & 33 & 34.7 & 29 & 30.5 & 19 & 20 & 2.47 \\
\hline 10 & Case study & 4 & 4.2 & 7 & 7.4 & 30 & 31.6 & 24 & 25.3 & 20 & 21.1 & 2.27 \\
\hline 11 & Practice on real situations & 5 & 5.3 & 9 & 9.5 & 25 & 26.3 & 31 & 32.6 & 25 & 26.3 & 2.34 \\
\hline \multicolumn{12}{|c|}{ Grand mean } & 2.81 \\
\hline
\end{tabular}

As shown in table 4.9, the data obtained from cadet's questionnaire also show that lecture, group works and question and answer used learning strategy that had been always used by $24.2 \%, 29.5 \%$ and $10.5 \%$ and they used those techniques frequently by $33.7 \%, 44.2 \%$ and $28.4 \%$. The mean value of lecture, group works $\&$ question and answer was 3.68, 3.95 and 3.08. This shows that in ARPC those three teaching techniques employed.

In Similar with the instructor respondents, cadets also rated other teaching techniques that listed in the table 4.8 above except the first three teaching techniques, those listed in item no. 4,5,6,7,8,9,10 and 11 were sometimes employed by ARPC instructors.

The grand mean of the cadet's response is 2.81 which are almost equal with the grand mean of instructor's response (3.14). This indicates different active learning techniques including lecture method employed in ARPC sometimes.

The data obtained from the open-ended question that made with instructors also showed that lecture was the most commonly used teaching technique followed by group works/discussions, each assignment and 'question and answer' teaching techniques. However, instructors also show that their lectures were mostly non interactive 
and traditional type.

The interviews revealed that demonstration, case study and peer teaching were the other commonly used techniques in the college. Other active learning techniques, including brainstorming, demonstration and practice in real settings have been mentioned by academic director and research department head.

In addition to the above questionnaire and interviews, the researcher confirmed that the process of active learning methodology at ARPC is at a low level, as observed in class room.

Overall, both the quantitative and qualitative data collected from instructors, cadets, research department head and the academic director of the college indicated that lecture was the most employed teaching technique followed by group works and question and answer.

Based on the analysis of quantitative and the qualitative data, we can say that there were practices of implementation of active learning method but traditional lecture method was the most dominant method in the college. Therefore, we can say that the level of implementation of active learning strategies in ARPC was low.

Table 4. 10 Class observation in teaching techniques evaluation on the current practice of active learning

\begin{tabular}{|c|c|c|c|c|c|}
\hline \multirow{3}{*}{ No. } & \multirow{3}{*}{ Item } & \multicolumn{2}{|c|}{ Yes } & \multicolumn{2}{|c|}{ No } \\
\hline & & \multicolumn{2}{|c|}{$\begin{array}{l}\text { Number } \\
\text { observation }\end{array}$} & \multicolumn{2}{|c|}{$\begin{array}{l}\text { Number } \\
\text { observation }\end{array}$} \\
\hline & & $\mathrm{F}$ & $\%$ & $\mathrm{~F}$ & $\%$ \\
\hline 1 & Lecture & 8 & 100 & - & - \\
\hline 2 & Group works & 5 & 62.5 & 3 & 37.2 \\
\hline 3 & Question and Answer & 4 & 50 & 4 & 50 \\
\hline 4 & Demonstration & 3 & 37.5 & 5 & 62.5 \\
\hline 5 & Problem solving & - & - & 8 & 100 \\
\hline 6 & Peer teaching & - & - & 8 & 100 \\
\hline 7 & Brainstorming & - & - & 8 & 100 \\
\hline 8 & Role playing & 3 & 37.5 & 5 & 62.5 \\
\hline 9 & Individual assignments/ home works & 2 & 25 & 6 & 75 \\
\hline 10 & Case study & - & - & 8 & 100 \\
\hline 11 & Practice on real situations & - & - & 8 & 100 \\
\hline
\end{tabular}

Table 4.10 above showed that all problem solving, peer teaching, brainstorming, case study and practice on real situation activities were not well performed by the instructors. According to the observation result, 100\% of the observed class instructors use lecture teaching techniques for their cadets. This indicated that the instructors only use lecture method on their class room. So we can say, there was a tendency of using lecture method by instructors.

\subsubsection{Factors Affecting the Practice of active learning methodologies}

Regarding factors which affect the implementation of active learning, instructors and cadets were asked to identify by very high, high, moderate, low and very low factors that affect the implementation of active learning in ARPC. The responses of instructor and cadet responders are summarized in the following tables (table 4.11 and 4.12) separately.

Table 4. 11 Factors affecting the practice of active learning methods in instructor's view

\begin{tabular}{|c|c|c|c|c|c|c|c|c|c|c|c|c|}
\hline \multirow[t]{2}{*}{ No. } & \multirow[t]{2}{*}{$\begin{array}{c}\text { Factors Affecting the Practice } \\
\text { of Active Learning }\end{array}$} & \multicolumn{2}{|c|}{ Very high } & \multicolumn{2}{|c|}{ High } & \multicolumn{2}{|c|}{ Moderate } & \multicolumn{2}{|c|}{ Low } & \multicolumn{2}{|c|}{$\begin{array}{l}\text { Very } \\
\text { low }\end{array}$} & \multirow[t]{2}{*}{ mean } \\
\hline & & $F$ & $\%$ & $F$ & $\%$ & $F$ & $\%$ & $\mathrm{~F}$ & $\%$ & $\mathrm{~F}$ & $\%$ & \\
\hline 1 & $\begin{array}{l}\text { Lack of skill about active } \\
\text { learning method on teacher }\end{array}$ & 3 & 9.7 & 8 & 25.8 & 19 & 61.3 & - & - & 1 & 3.2 & 3.39 \\
\hline 2 & $\begin{array}{l}\text { Lecturers' tendency to use } \\
\text { traditional/ lecture methods }\end{array}$ & 7 & 22.6 & 8 & 25.8 & 14 & 45.2 & 2 & 6.5 & - & - & 3.65 \\
\hline 3 & $\begin{array}{l}\text { Lack of administrative } \\
\text { support }\end{array}$ & 8 & 25.8 & 12 & 38.7 & 7 & 22.6 & 1 & 3.2 & 3 & 9.7 & 3.68 \\
\hline 4 & $\begin{array}{l}\text { Students and teachers } \\
\text { knowledge of the students- } \\
\text { centered method of learning }\end{array}$ & 6 & 19.4 & 9 & 29 & 12 & 38.7 & 2 & 6.5 & 2 & 6.5 & 3.48 \\
\hline 5 & Large class size & 19 & 61.3 & 9 & 29 & 3 & 9.7 & - & - & - & - & 4.52 \\
\hline 6 & $\begin{array}{l}\text { Lack of materials or } \\
\text { equipment needed to support } \\
\text { active learning }\end{array}$ & 15 & 48.4 & 11 & 35.5 & 4 & 12.9 & 1 & 3.2 & - & - & 4.29 \\
\hline 7 & $\begin{array}{l}\text { Students lack of interest on } \\
\text { active learning methods }\end{array}$ & 9 & 29 & 8 & 25.8 & 12 & 38.7 & 1 & 3.2 & 1 & 3.2 & 3.74 \\
\hline \multicolumn{12}{|c|}{ Grand mean } & 3.82 \\
\hline
\end{tabular}


In the above table 4.11 , According to instructors rating of the factors, large class size/ $(90.3 \%)$, lack of administrative support (64.5\%), lack of materials or equipment needed to support active learning $(83.9 \%)$ and Students lack of interest on active learning methods $(54.8 \%)$ were rated as the most serious factors that have been negatively affecting the utilization of active learning strategies in ARPC.

As it is shown in the table 4.11 , other factors which were rated as moderate factors by majority of instructors are lecturers' tendency to use traditional/ lecture methods (48.4\%), students and teacher's knowledge of the students-centered method of learning (48.4\%) and lack of skill about active learning method on teacher $(35.5 \%)$.

The grand mean of the instructor responses was 3.82, which shows that the instructors were confirmed that those factors that are listed on the table 4.11 were serious factors which hindered the implementation of active learning during their teaching in ARPC.

Table 4. 12 Factors affecting the practice of active learning methods in cadet's view

\begin{tabular}{|c|c|c|c|c|c|c|c|c|c|c|c|c|}
\hline \multirow[t]{2}{*}{ No. } & \multirow{2}{*}{$\begin{array}{c}\text { Factors Affecting the } \\
\text { Practice of Active } \\
\text { Learning }\end{array}$} & \multicolumn{2}{|c|}{ Very high } & \multicolumn{2}{|c|}{ High } & \multicolumn{2}{|c|}{ Moderate } & \multicolumn{2}{|c|}{ Low } & \multicolumn{2}{|c|}{ Very low } & \multirow[t]{2}{*}{ mean } \\
\hline & & $\bar{F}$ & $\%$ & $\mathrm{~F}$ & $\%$ & $\mathrm{~F}$ & $\%$ & $\mathrm{~F}$ & $\%$ & $\mathrm{~F}$ & $\%$ & \\
\hline 1 & $\begin{array}{l}\text { Lack of skill about active } \\
\text { learning method on } \\
\text { teacher }\end{array}$ & 14 & 14.7 & 23 & 24.2 & 48 & 50.5 & 9 & 9.5 & 1 & 1.1 & 3.42 \\
\hline 2 & $\begin{array}{l}\text { Lecturers' tendency to use } \\
\text { traditional/ } \\
\text { methods }\end{array}$ & 5 & 5.3 & 23 & 24.2 & 43 & 45.3 & 22 & 23.2 & 2 & 2.1 & 3.07 \\
\hline 3 & $\begin{array}{l}\text { Lack of administrative } \\
\text { support }\end{array}$ & 22 & 23.2 & 15 & 15.8 & 22 & 23.2 & 24 & 25.3 & 12 & 12.6 & 3.11 \\
\hline 4 & $\begin{array}{l}\text { Students and teachers } \\
\text { knowledge of the } \\
\text { students-centered method } \\
\text { of learning }\end{array}$ & 10 & 10.5 & 22 & 23.2 & 39 & 41.1 & 20 & 21.1 & 4 & 4.2 & 3.14 \\
\hline 5 & Large class size & 22 & 23.2 & 23 & 24.2 & 29 & 30.5 & 14 & 14.7 & 7 & 7.4 & 3.41 \\
\hline 6 & $\begin{array}{lcc}\text { Lack of materials } & \text { or } \\
\text { equipment } & \text { needed } & \text { to } \\
\text { support active learning } & \\
\end{array}$ & 32 & 33.7 & 24 & 25.3 & 13 & 13.7 & 16 & 16.8 & 10 & 10.5 & 3.54 \\
\hline 7 & $\begin{array}{l}\text { Students lack of interest } \\
\text { on active learning } \\
\text { methods }\end{array}$ & 15 & 15.8 & 18 & 18.9 & 34 & 35.8 & 19 & 20 & 9 & 9.5 & 3.11 \\
\hline \multicolumn{2}{|c|}{ Grand mean } & & & & & & & & & & & 3.25 \\
\hline
\end{tabular}

As it is shown in table 4.12 above, $59 \%$ of cadet respondents think that lack of materials or equipment needed to support active learning the most serious factor, $47.4 \%$ of respondents indicated that large class was a serious factor, $39 \%$ and $38.9 \%$ of respondents show that lack of administrative support and lack of skill about active learning method on teacher were negatively affect to implement active learning in ARPC respectively. These indicate that other serious factors that were rated by instructor respondents are also supported by cadet respondents.

The grand mean of cadet's response was 3.25 which show that the above listed factors affect the implementation of active learning negatively.

Research department head and the academic director of the college were also asked about the factors that affect the implementation of active learning method in the college during the interview. In the same way, they revealed the following problems as serious factors which hindered the implementation of active learning.

Shortage of time, lack of skill to practice different teaching techniques due to lack of pre service trainings and inadequacy of in-service trainings on teaching methodologies, student lack of interest on active learning methodology ,shortage of necessary resources, lack of enough administrative support, large number of students in classroom were the factor that hinder to practice active learning in ARPC.

The interview with the academic director and research department head additionally revealed that instructors and cadets' tendency to use the traditional/ lecture method and lack of commitment to implement active learning methodology and large class size were the most serious factors that hindered their practice of active learning. The interview report also indicated that many but not all instructors had taken Training of trainer /TOT/ and other trainings on active learning methodology. However, some instructors may lack some skills to practice active learning strategies because of trainings on teaching methodologies were inadequate.

Other factors that rated as serious factors by cadets and instructors were also revealed by open-ended question, Shortage of time, large amount of contents, organization of the curriculum and lack of continuous 
monitoring and administrative support were also the other serious factors that raised by the academic director, research department head and cadets.

Table 4. 13 Class observation in use of instructional materials on the current practice of active learning

\begin{tabular}{|l|l|l|l|l|l|}
\hline \multirow{2}{*}{ No. } & \multicolumn{2}{|c|}{ Item } & \multicolumn{2}{c|}{ yes } & \multicolumn{2}{c|}{ No } \\
\cline { 3 - 6 } & & Number of observation & \multicolumn{2}{l|}{ Number of observation } \\
\cline { 3 - 6 } & & F & $\%$ & F & $\%$ \\
\hline 1 & Are there charts, posters, diagrams? & - & - & 8 & 100 \\
\hline 2 & $\begin{array}{l}\text { Does the instructor use the instructional materials } \\
\text { other than books, charts, posters? }\end{array}$ & 2 & 25 & 6 & 75 \\
\hline 3 & $\begin{array}{l}\text { Does the instructor illustrate ideas using instructional } \\
\text { materials? }\end{array}$ & - & - & 8 & 100 \\
\hline
\end{tabular}

Accessibility of instructional materials in classroom was one factor that to enhance the whole process of education. In table, 4.13 the observation result indicates that in the $100 \%$ of the observed classes, there was no instructional material. Moreover in $75 \%$ of the observed classes, the instructors do not use instructional materials. To sum up, the use of instructional materials in the observed classes was found to be at a low level. This showed lack of materials or equipment needed to support active learning.

\subsection{Discussion of Results}

In this study, an attempt is made to explain the results of the study with reference to the basic questions formulated understatement of the problem. The major ideas or theme of the discussion questions are:

1. How do Amhara Region Police College instructors and cadets perceive active-learning?

2. To what extent active learning is implementing in Amhara Police College?

3. What are the challenges that affect the implementation of active learning?

\subsubsection{Amhara Region Police College instructors and cadets perception of active-learning}

The literature part of this study showed that the attitude of teachers and students on active learning play a vital role to implement active learning. Different authors confirmed that there is strong tie between instructors' and students' attitudes towards active learning and their effort in implementing it. For example, (Capel et. al., 1995), pruved that the belief persists that active learning takes too much time and thus covering the portion is difficult or impossible. Even, they come to the conclusion that active learning may be nice in theory but unrealistic in practice. These all show that there have been no enough and concrete perception about how to install active learning in classroom, which may lead to negative reactions. Similarly (Dary and Terry, 1993), posative percetion of students lead into effactive implemntation of active learning. But students percive active learning negatively, they do not challenge there old assumption, they do not create new meaning or perspectives that are more inclusive, integrative and open to alternative views, which can emancipate them from strong belief on stimulus response mechanisms.

In line with these ideas, 12 items questionnaire for the instructors and cadets were included in the questionnaires with the intention of assessing their perception of active learning. In consistent this research finding, the study revealed that most instructors and cadets mostly have a positive perception towards active learning method. This shows that cadets and instructors could be a good implementer if they committed to carry out active learning method and if conducive, environment will create in the college. But their positive perception doesn't let them to practice active learning in ARPC. This is also confirmed by researcher during respondents of interviewed and the classroom observation. Therefore, to carry out active learning, proper measures taken to bring full attitudinal change in cadets and instructors by filling the gap on their perception of how to practice active learning.

\subsubsection{Practices of active learning in Amhara Region Police College}

To assess the practices of active learning in Amhara Region Police College the researcher try to identify different mechanisms of active learning implementation. From those mechanisms group work/discussion groups, questioning, think-pair-share, demonstration, role play, brainstorming, case studies, project method and peer teaching are the most common and widely utilized teaching techniques which encourage students to have active involvement in classroom and understand the subject in a better way out of the class.

To prove the practices of active learning in Amhara Region Police College questionnaires were develop for instructors and cadets separately to determine the frequency of using active learning in the college by indicating how often use active learning in the time of teaching learning process.

Accordingly, the instructors identified the frequency with which they implement active learning from the responses of the questionnaire and observation. These data indicate that ARPC instructors practices active learning infrequently in their classroom. The responses of the instructors to question related to their use of active learning were validated by the responses of the cadets.

The data obtained from the open-ended question that made with instructors also showed that lecture was the most commonly used teaching technique followed by group works/discussions, each assignment and 'question and answer' teaching techniques. However, instructors also show that their lectures were mostly non interactive 
and traditional type.

The interviews revealed that demonstration, case study and peer teaching were the other commonly used techniques in the college. Other active learning techniques, including brainstorming, demonstration and practice in real settings have been mentioned by academic director and research department head.

In addition to the above questionnaire and interviews, the researcher confirmed that the process of active learning method at ARPC is at a low level, as observed in class room.

Overall, both the quantitative and qualitative data collected from instructors, cadets, research department head and the academic director of the college indicated that lecture was the most employed teaching technique followed by group works and question and answer.

Based on the analysis of quantitative and the qualitative data, we can say that there were practices of implementation of active learning method but traditional lecture method was the most dominant method in the college. Therefore, we can say that the level of implementation of active learning strategies in ARPC was low.

4.3.3. Challenges that affect the implementation of active learning in Amhara Region Police College

In the time of teaching-learning process, active learning too may face different factors during its implementation in the real classroom conditions. The researcher has selected seven possible factors affecting the implementation of active learning in ARPC.

Shortage of time, lack of skill to practice different teaching techniques due to lack of pre service trainings and inadequacy of in-service trainings on teaching methodologies, student lack of interest on active learning method, shortage of necessary resources, lack of enough administrative support, large number of students in classroom were the factor that hinder to practice active learning in ARPC.

Generally different researcher and author found that the practices of active learning in educational institution were low because of the lack of budget, large class size, due to the perception of teachers about active learning, lack of training are the factors that hinder the implementation of active learning (Daniel, 2014), (Teshome, 2017), (Mulatu \& Bezabih, 2018), (Biruh, 2018). In this study the researcher confirmed that those factors that are listed by authors and researchers are factors that hinder the practices of active learning in ARPC.

\section{Unit five}

\section{Findings, Conclusion and Recommendations}

This chapter deals with summaries of the major findings, conclusion and recommendations that have been made on the basis of the results in chapter four.

\subsection{Findings}

The main purpose of this study was to assess the current practice of active learning approaches in Amhara Region Police College. In order to accomplish this objective of the study, the following three specific questions were formulated.

1. How do Amhara Region Police College instructors and cadets perceive active-learning?

2. To what extent active learning is implementing in Amhara Police College?

3. What are the challenges that affect the implementation of active learning?

To answer these research questions, mixed methods research design was employed. $3^{\text {rd }}$ round regular diploma cadets, instructors, the academic director and research department head of Amhara Region Police College were the target population of the study. Using simple random sampling method cadets of $3^{\text {rd }}$ round regular diploma cadets were selected and all 95 students from the $3^{\text {rd }}$ round diploma cadets, and 31 instructors' were selected using senses method and availability sampling. The academic director of the college and research department head were also participated in the study. A total of 128 people were part of the study.

Questionnaires observation and interviews were the tools that were used to collect the data from the sample. Both quantitative and qualitative methods were used in analyzing the data obtained through questionnaires and interviews. The quantitative data were analyzed using frequencies, percentages and mean scores. On the other hand, the qualitative data were analyzed by using descriptive statements. Finally, quantitative and qualitative results were merged to look answers for the main research question of the study and the following major findings were obtained.

\subsubsection{Major findings on instructors and students understanding of active learning}

The data from analysis of instructors and cadets' questionnaire showed that number of instructors and cadets showed their agreement with the majority of assumptions of active learning that was raised in the questionnaires. Generally, it was found that majority of the instructors and cadets have a good understanding of active learning.

\subsubsection{Major findings on the current practice of active learning methods}

In general, the analysis of data showed that there was some practice of active learning in Amharia Region Police College.

- Based on the findings from the teachers and cadets survey, it is confirmed that there was a practice of different active learning techniques sometimes and that lecture method was the most frequently 
employed technique.

- On the other hand, the interview reports indicated that traditional lecture method, which is non interactive, was regularly employed method and the practice of different active learning techniques were not satisfactory.

- One's can say that there were practices of implementation of active learning method but traditional lecture method was the most dominant method in the college. Therefore, we can say that the level of implementation of active learning strategies in ARPC was low.

- The study also revealed that that lecture was the most commonly used teaching technique followed by group works/discussions, each assignment and 'question and answer' teaching techniques. In addition to this, lecture was mostly non interactive and traditional type.

\subsubsection{Major findings on Factors affecting the implementation of active learning in Amhara Rigon Police College}

The study revealed that various factors contributed to the low level of implementation of active learning methodologies in ARPC. Large class size, lack of administrative support, Lack of materials or equipment needed to support active learning and Students lack of interest on active learning methods were rated as the most serious factors that have been negatively affecting the utilization of active learning strategies in ARPC. Other factors which have been seriously affecting the implementation of active learning strategies are listed in below.

$>$ Shortage of time

$>$ Lack of skill to practice different teaching techniques due to lack of pre service trainings and inadequacy of in-service trainings on teaching methodologies

$>$ Student lack of interest on active learning methodology

$>$ Shortage of necessary resources

$>$ Lack of enough administrative support

$>$ Large number of students in classroom

$>$ Instructors tendency to use the traditional/ lecture method and lack of commitment to implement active learning methodology

\subsection{Conclusions}

Based on the major findings of the study, the following conclusions were drawn:

Even though there are few practices of active learning in Amhara Police College, the practice of active learning in the college was not founded satisfactory because instructors and cadets confirmed that lecture method was the most frequently employed technique and the interview reports revealed that traditional lecture method, which is non interactive, was regularly in working method and the practice of different active learning techniques were not satisfactory.

Considering the level of utilization of different active learning techniques, individual assignments, group work/discussion and question and answer methods were found to be the most commonly employed techniques next to the lecture method.

Regarding to the factors that affects the implementation of active learning in Amhara Region Police College, large class size, lack of administrative support, lack of materials or equipment are needed to support active learning and students lack of interest on active learning methods were rated as the factors that have been negatively affecting the utilization of active learning strategies in ARPC. Additionally, shortage of time, lack of skill to practice different teaching techniques due to lack of pre service trainings and inadequacy of in service trainings on teaching methodologies, instructor's tendency to use the traditional/ lecture method and lack of commitment to implement active learning was the factors that hinder to implement active learning in Amhara Region Police College.

With regard to instructors and cadets understanding of active learning, the findings showed that almost all the instructors and cadets have perceived active learning positively but they didn't practice it.

\subsection{Recommendations}

Based on the conclusions drawn above, the following recommendations were advanced to improve the implementation of active learning.

- As the findings discovered, majority of the instructors have a positive understanding of active learning but their practice of active learning was not satisfactory. Thus, it is recommended that instructors should be committed to discharge their roles to exercise active learning in Amhara Region Police College.

- The level of use of active learning can be enhanced if the instructors are able to provide the circumstances that encourage active participation of students in the teaching learning process regularly.

- The administration of the college and other stakeholders should design and implement a mechanism to monitor the practice of active learning regularly. 
- The result of this study identified that shortage of time were the factors which hindered the practice of active learning. So, the concerned bodies of the college should design different mechanisms to avoid these problems by appropriately allocating the time, revising crowded materials and avoiding large and unnecessary contents.

- Instructors and cadets tendency towards traditional lecture method was also another problem in the college. To avoid this problem, the college should prepare different trainings, seminars and courses to bring attitudinal change on the minds of instructors and cadets of the college.

Generally, to recover all factors that were contributing to the low practice of implementation of active learning in Amhara Region Police College, the administration of the college should continuously identify and solve those problems by developing a working group in coordination with instructors, cadets and other stakeholders.

\section{List of reference}

Alston, M., \& Bowles, W. (2018). Research for social workers: An introduction to methods. Aotearoa New Zealand Social Work, 30(3), 96. Https://doi.org/10.11157/anzswj-vol30iss3id549

Amare, A. (1999). Availability and Use of Instructional Materials in Tigray Primary Schools. 7(1), 53-66.

Amhara Region Police College. (2015). Regular Diploma Curriculum in Police Science.

Augustine, F. L., Bozylinsky, J. M., Folley, V. L., Lynch, P. P., O’Keefe, J. A., Lentini, J. R., Pantaleoni, C. A., Riddle, D. H., Schildecker, C. B., Schonfeid, N. R., Stinchcomb, J. D., Styles, J. C., \& Velzy, R. J. (1976). LAW ENFORCEMENT TECHNOLOGY. U.S. Government Printing Office. Https://doi.org/017-080-01402

Belihu, G. A. (2010). Tension between traditional and modern teaching-learning approaches in Ethiopian primary schools. Proceedings of World Conference on Educational Multimedia, Hypermedia and Telecommunications 2010, 9(1), 2617-2628.

Best, J.W. and Kahn, J. (1997). Research in Education (7th ed.).

Birhanu, M. (2010). Active learning approaches in mathematics education at universities in Oromia, Ethiopia (Issue November). UNIVERSITY OF SOUTH AFRICA.

Biruh, A. (2018). An Assessment of Practice of Active Learning Approach in Wolita Sodo University Health Science College, Southern Ethiopia: The Case of Preclinical Classes.

Bixley, B., \& Yamane, T. (1965). Statistics: An Introductory Analysis. The Canadian Journal of Economics and Political Science, 31(1), 163. Https://doi.org/10.2307/139661

Bonwell, C., \& Eison, J. (1991). Active learning: creating excitement in the classroom /. School of Education and Human Development, George Washington University.

Borich, G. D. (1984). Effective Teaching Methods. Macmillan Publishing Company.

Brewerton, P., \& Millward, L. (2001). Organizational Research Methods. SAGE Publications.

Caffarella, R., \& Merriam, S. (1999). Learning in adulthood: A comprehensive guide. San Francisco: JosseyBass.

Capel et. Al. (1995). Learning to Teach in the secondary Schools. London: Rutledge.

Charles, C., \& James, A. (1991). Active learning Creating Excitement in the Classroom.

Chervase, C. (2016). Active methods for language learning. "Alexandru Ioan Cuza" Police Academy, Bucharest, RomaniaCchervase@yahoo.Co.UkABSTRACT, 2(2).

Daniel, Y. (2014). The Implementation of Active Learning and Continuous Assessment in Pentecostal Theological College. June.

Dary, N. And Terry, E. (1993). Reforming Open and Distance Education: Critical Reflection Practice. London: Kogan Page.

Debela, W. (2017). Implementation of student-centered approach in teaching physicaleducation class room. The case of some selected high schools in Lalo Assabi Woreda,West Wollega Zone, Western Ethiopia (Issue March). Haramaya University, Ethiopia.

Dekanoidze, K., \& Khelashvili, M. (2018). Police education and training systems in the OSCE region. Https://www.osce.org/files/f/documents/f/7/423401.pdf

Desalegn, G. (2014). The implementation of active learning approach in teaching algebra in secondary schools of East Wollega Zone, Oromia Regional State. Addis Ababa University.

Desta, A. (2001). Factors Influencing The Implementation of Problem Solving Approach In The Second Cycle Primary Schools of Tigray (Issue June). Addis Ababa University.

Déverge, C. A. (2016). Police Education and Training: A Comparative Analysis of Law Enforcement Preparation in the United States and Canada.

E. Dale. (1969). Dale's Cone of Experience.

Eggen, P. ., \& Kauchax, D. P. (1996). Strategies for Teachers: Teaching Content and Thinking Skills. Boston: Allyn and Bacon.

Fink, L. D. (2003). A Self-Directed Guide to Designing Courses for Significant Learning. San Francisco: Jossey- 
Bass.

Frazee, \& Al, M. B. Et. (1995). Integrated Teaching Methods: Theory Classroom Approach., and field based Connections (New York:).

Fritsvold, E. (2020). Going Beyond the Bachelor's: Why Police Officer Education is So Important. University of San Diego. Https://onlinedegrees.sandiego.edu/why-police-officer-education-is-important/

Gara, L., \& Asrat, D. (2014). Attitude of teachers towards the use of active learning methods.

Gupta, N. K., Banerjee, K., Uppal, S., Ganguly, G., John, M., \& Srivastava, S. (2014). Basics in Education. Http://www.ncert.nic.in/pdf_files/basic_in_education.pdf

Haarr, R. N. (2001). T he $m$ aking of a c ommunity $p$ olicing o fficer : $t$ he $i$ mpact of $b$ asic $t$ raining and $o$ ccupational s ocialization. 4(4).

ICDR. (1999). Teacher Education Hand Book. Adiss Abba Finfine Printing and Publishing.

John, P. (2012). Meaning, Nature and Aims of Education.

Kirpik, C. (2012). Active learning in history and social studies.

Kooi, G. P. Vander. (2006). Problem-Based Learning : an Attitudinal Study of Police Academy Students.

Kothari, C. R. (2004). Research methodology: methods and techniques. In New Age International (2nd ed.).

Https://doi.org/http://196.29.172.66:8080/jspui/bitstream/123456789/2574/1/Research\%20Methodology.pdf

Kumar, S., \& Sajjad Ahmad. (2008). True meaning of education. In MEANING, AIMS AND PROCESS OF EDUCATION (pp. 1-92). University of Delhi. Https://doi.org/110007

Kyriacou, C. (2007). Essential teaching skills. In Bmj (3rd ed., Vol. 335, Issue Suppl S4). Nelson Thornes Ltd. Https://doi.org/10.1136/sbmj.0710361

Latefy, S. (2016). THEORETICAL FOUNDATIONS OF ACTIVE LEARNING.

Macharia, S. N., \& Waria. (1994). Teaching Practice in Primary Schools. Hong Kong:Macmillan Publishing Company.

Mcleod, G. (2001). Learning Theory and Instructional Design. 35-43.

Mebratu, Mulatu \& Woldemariam, B. (2018). The Effects of Teachers' Perceptions on the Implementations Active Learning in EFL Classroom: The Case of Three Selected Secondary Schools in Dawro Zone, SNNPRS, Ethiopia. 18(6).

Michael, P. (2004). Does Active Learning Work? A Review of the Research. In Department of Chemical Engineering Bucknell University (Vol. 93, Issue July).

Morgan, J., Barroso, L. R., \& Simpson, N. (2014). Active Demonstrations for Enhancing Learning. June. Https://doi.org/10.1109/FIE.2007.4418057

Mulatu \& Mebratu. (2018). Perceptions and Practices of EFL Teachers in Implementing Active Learning in English Classes: The Case of Three Selected Secondary Schools in Dawro Zone, Snnprs, Ethiopia. Journal of Literature, Languages and Linguistics, 41, 26-33.

Nurma, W. (2017). Active learning models using techniques learning start with a question to increase liveliness of students in accounting learning class xi accounting 1 smk negeri 1 yogyakarta academic year 2016/2017.

Orey, M. (2014). Emerging Perspectives on Learning,Teaching, and Technology. In M. Drexel (Ed.), Primary Teaching Assistants: Curriculum in Context. The Global Text Project is funded by the Jacobs Foundation. Https://doi.org/10.4324/9780203422090

Ormrod, J. E. (2012). Human learning (Lauren Carlson (ed.); 6th ed.). Pearson Education, Inc.

Ornstein, A., \& Hunkins, F. (2009). Curriculum Design. In Curriculum: Foundations, Principles and Issues. 5th Ed, 181-206.

Peggy, M. (2016). Active Learning. In Active Learning Definitions and Toolkit of Online Resources Prepared for the UNMC College of Medicine Curriculum Leadership (pp. 1-2).

Pual, B., Harrrison, C., Lee, C., Marshall, B., \& Wiliam, D. (2005). Putting it into practice Assessment for Learning Putting it into practice (7th ed.). Open university press.

Ramsden, P. (1993). Learning to Teach in Higher Education. In Studies in Higher Education (Vol. 18, Issue 1). Https://doi.org/10.1080/03075079312331382498

Rudolph, A. R., \& Orwin, C. (2005). Active . Learning. 3, 1-7.

Ryan, C. M. (2008). Pedagogy, police training, D/ discourses - subcultures and situated identities and meanings. 1-13.

Sasikumar, N. (2018). Impact of active learning strategies to enhance student. Innoovare Journal of Education, December.

Saunders, M., Lewis, P., \& Thornhill, A. (2009). Research Methods for Business Students (5th ed.).

Shipton, B. (2009a). J ournal of Learning Design. 3(1), 57-67.

Shipton, B. (2009b). Problem Based Learning: Does it provide appropriate levels of guidance and flexibility for use in police recruit education? Journal of Learning Design, 3(1), 57-67.

Silberman, M. (1996). Introduction to active learning. Active Learning: 101 Strategies to Teach Any Subject, 121. 
Tavares-dos-Santos, J. V. (n.d.). Police Education an approach frem Brazil.

Taye Geressu. (2008). Perceptions and practices of active learning in EFL classes of Dilla University. In Department of Biotechnology - College of Science - University of Baghdad. Baghdad, Iraq: Vol. Volume 49 (Issue Ethnic Journal of Science) (Vol. Vol49, Issue The Ethnic Journal of Science).

Tesfaye, S. (2015). Improving Students 'Participation in Active Learning Methods: Group Discussions , Presentations And Demonstrations: A Case of Madda Walabu University Second Year Tourism Management Students of 2014. 6(22), 29-33.

Teshome, N. (2017). Classroom Participation and Development of Student Attitudes: A Study of Active Learning Practices in Ethiopian Primary Education. International Journal of Humanities Social Sciences and Education (IJHSSE), 4(3), 67-85.

THE COUNCIL OF THE AMHARA NATIONAL REGIONAL STATE. (2007). Regulation No.53/2007 The Amhara National Regional State Police College Establishment, Council of Regional Government Regulation. 16, 1-15.

Tricia, W. (2019). 9 benefits of active learning.

Vodde, R. F., \& Robert, F. (2009). Andragogical Instruction for Effective Police Training Andragogical Instruction for Effective Police Training. 716, 19-20.

Weimer, M. (2012). Principles of Active Learning.

Weisburd, D., \& Neyroud, P. (2011). New Perspectives in Policing Police Science: Toward a New Paradigm. National Institute of Justice.

Yin, X., Zhang, J., \& Wang, X. (2004). Sequential injection analysis system for the determination of arsenic by hydride generation atomic absorption spectrometry. Fenxi Huaxue, 32(10), 1365-1367. Https://doi.org/10.1017/CBO9781107415324.004

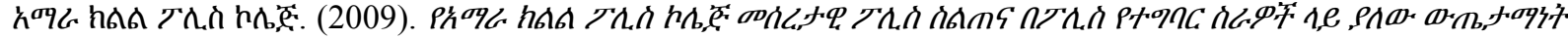
P.९nd TSt. 